\title{
Upper ocean carbon fluxes in the Atlantic Ocean: The importance of the POC:PIC ratio
}

\author{
Wolfgang Koeve \\ Marum, FB Geowissenschaften, Universität Bremen, Bremen, Germany
}

Received 20 November 2001; revised 13 May 2002; accepted 15 May 2002; published 15 October 2002.

[1] The mean depth distribution of the POC:PIC ratio of sinking particles, measured with particle interceptor traps deployed in the Atlantic Ocean, is fitted by an exponential function (POC:PIC $=64.3 Z^{-0.56} ; r^{2}=0.69$ ) The function is successfully evaluated by comparison with (a) estimates of the POC:PIC ratio of export production, computed from seasonal changes of nitrate and alkalinity and (b) estimates of the POC:PIC ratio of remineralization on shallow isopycnals. The basin mean POC:PIC ratio of export production is 4.2-4.37. The POC:PIC-depth function is combined with empirical relationships between the flux of particulate organic matter, primary production and depth, satellite derived primary production data sets, and the regional distribution of $\psi$ (the ratio of released $\mathrm{CO}_{2}$ :precipitated carbonate during $\mathrm{CaCO}_{3}$ formation) in order to estimate the effective carbon flux $\left(J_{\text {eff }}\right)$ in the Atlantic Ocean. Remineralization of organic carbon above the winter mixed layer $(11-17 \%)$ and $\mathrm{CaCO}_{3}$ sequestration from the winter mixed layer (13-16\%), which is the balance between $\mathrm{CaCO}_{3}$ production and shallow dissolution, are the two main processes which control the difference between export

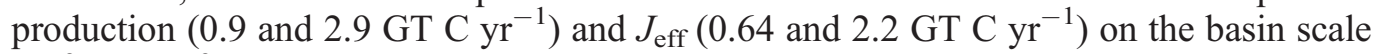
$\left(65^{\circ} \mathrm{N}\right.$ to $\left.65^{\circ} \mathrm{S}\right) . \mathrm{CaCO}_{3}$ sequestration is the dominant process modulating effective carbon export in the tropics, while shallow POC remineralization dominates in temperate and polar waters. Observed regional patterns like polarward increases of the POC:PIC export ratio and of $\psi$ counteract each other largely when $J_{\text {eff }}$ is computed. INDEX TERMS: 4203 Oceanography: General: Analytical modeling; 4806 Oceanography: Biological and Chemical: Carbon cycling; 4863 Oceanography: Biological and Chemical: Sedimentation; KEYWORDS: carbon cycle, particle flux, Corg:Cinorg ratio, effective carbon export, biological pump, Atlantic Ocean

Citation: Koeve, W., Upper ocean carbon fluxes in the Atlantic Ocean: The importance of the POC:PIC ratio, Global Biogeochem. Cycles, 16(4), 1056, doi:10.1029/2001GB001836, 2002.

\section{Introduction}

[2] The biological pump [Volk and Hoffert, 1985] drives a net flux of fixed organic carbon from the surface of the ocean into its interior. This flux, and the subsequent remineralization in the deep ocean produces a vertical gradient of total $\mathrm{CO}_{2}$, which controls the steady state $\mathrm{CO}_{2}$ level of the atmosphere [Shaffer, 1993]. To determine the effectiveness of this carbon flux is at the heart of carbon cycle studies in the ocean [SCOR, 1990; Fasham et al., 2001]. Export production [Eppley and Peterson, 1979], which is the sum of all organic carbon fluxes (particulate and dissolved organic carbon, POC and DOC) from the productive surface of the ocean, has often been referred to as a suitable measure of this effectivity. However, a significant fraction of the carbon export is remineralized within the upper few hundred meters [Martin et al., 1987; Louanchi and Najjar, 2000] and nutrients and $\mathrm{CO}_{2}$ stemming from

Copyright 2002 by the American Geophysical Union. 0886-6236/02/2001GB001836 shallow remineralization can be recirculated to the surface ocean on short timescales of about a year and do not contribute to the vertical inner-ocean $\mathrm{CO}_{2}$ gradient.

[3] Additionally, a fraction of the organic carbon export is compensated by the export of particulate inorganic carbon $\left(\mathrm{PIC}, \mathrm{CaCO}_{3}\right)$. This latter compensation is due to the net effect of $\mathrm{CaCO}_{3}$ production and export on the surface ocean $p \mathrm{CO}_{2}$. During formation of one mole of $\mathrm{CaCO}_{3}$, alkalinity is reduced by two moles and total dissolved inorganic carbon decreases by one mole. In combination, these changes cause a shift in the carbonate system toward a higher $\mathrm{CO}_{2}-$ concentration and hence a higher $p \mathrm{CO}_{2}$ [Broecker and Peng, 1982; Robertson et al., 1994; Frankignoulle et al., 1994; Buitenhuis et al., 2001]. Like for organic carbon, sequestration of particulate inorganic carbon to the deep ocean is the balance between $\mathrm{CaCO}_{3}$ production and shallow dissolution of $\mathrm{CaCO}_{3}$. Hence, new carbon production, shallow remineralization of $\mathrm{POC}$ and the countereffective production, export and shallow dissolution of PIC must be considered to obtain a correct estimate of the carbon flux which is effective with respect to the steady state mean $p \mathrm{CO}_{2}$ of the surface ocean. 
[4] A useful measure of the effectivity of the biological pump is the net export of carbon, which reaches into water masses which are isolated from exchange with the atmosphere on decadal to centennial timescales, here referred to as $J_{\text {eff. }}$ To estimate $J_{\text {eff }}$ the export and the shallow remineralization and dissolution of POC and PIC need to be specified. However, we have a modest understanding of the large-scale patterns and integrals of these properties. Direct estimates of POC or PIC export from the euphotic zone, based on drifting particle interceptor traps [Zeitzschel et al., 1978; Asper, 1996], are sporadic, short term in nature (days to weeks; Martin et al. [1993]), and methodologically questionable [Gust et al., 1992; Kähler and Bauerfeind, 2001]. In particular, very few examples exist, which resolve the depth distribution of PIC fluxes in the upper ocean [Martin et al., 1993]. Model-based estimates can fill some of these gaps. Ocean carbon cycle models have provided estimates of new production [Najjar et al., 1992; Sarmiento et al., 1993; Six and Maier-Reimer, 1996; Oschlies et al., 2000], however, few such models [e.g., Bacastow and Maier-Reimer, 1990] included a formal description of the inorganic carbon cycle. Modeling of $\mathrm{CaCO}_{3}$-related processes has usually restricted itself to dissolution at and below the lysocline in the deep ocean and in the sediments [Archer, 1991, 1996; Sigman et al., 1998]. The production and fate of $\mathrm{CaCO}_{3}$ in the upper ocean have rarely been studied quantitatively using ocean carbon cycle models [Yamanaka and Tajika, 1996; Archer et al., 2000a]. Recently, one of these model studies [Yamanaka and Tajika, 1996] has challenged the paradigmatic idea that the POC:PIC ratio of the ocean is about 4-5 [Li et al., 1969; Broecker and Peng, 1982] and suggested values between 10 and 12.5. Solving this issue is of great importance for the understanding of suspected changes in the production of $\mathrm{CaCO}_{3}$ [Riebesell et al., 2000; Zondervan et al., 2001] and their feedback on the future net $\mathrm{CO}_{2}$-uptake of the ocean.

[5] Linking maps of primary production [e.g., Berger, 1989; Longhurst et al., 1995; Antoine and Morel, 1996; Antoine et al., 1996; Behrenfeld and Falkowski, 1997] with empirical relationships between particle flux $(J)$, primary production (PP), and trap deployment depth $(Z)$ [Suess, 1980; Betzer et al., 1984; Hargrave, 1985; Pace et al., 1987; Berger et al., 1987 in the following referred to as $J$-PP- $Z$ functions] provide an independent approach for basin scale estimates of POC fluxes in the ocean [Antia et al., 2001]. These basin-scale POC flux estimates can be combined with empirical relationship of the POC:PIC flux ratio and water depth for the estimation of $J_{\text {eff }}$ [Antia et al., 2001].

[6] Recently Antia et al. [2001] and Koeve (W. Koeve, New production and shallow remineralization in the Atlantic Ocean-uncertainties and limitations of particle flux algorithms, submitted to Journal of Marine Research, 2001; in the following referred to as Koeve (submitted manuscript, 2001) estimated upper-ocean carbon fluxes for the Atlantic Ocean based on this empirical approach). A basin wide integrated carbon export production of 3.14 GT $\mathrm{C} \mathrm{yr}^{-1}$ (equivalent to a mean $f$-ratio of 0.33 ) was estimated from a newly derived $J$-PP- $Z$ function [Antia et al., 2001]. POC fluxes were integrated over mixing cycles (i.e., from winter to winter) and corrected for trapping inefficiencies by applying Th-calibration [Scholten et al., 2001]. Remineralization above the winter mixed layer was about $5.7 \%$ of export production and compensation due to $\mathrm{CaCO}_{3}$ export from the winter mixed layer reduced the carbon flux by another 16.5\%. Antia et al. [2001] estimate the effective carbon export of the Atlantic Ocean to be $2.47 \mathrm{GT} \mathrm{C} \mathrm{yr}^{-1}$. Koeve (submitted manuscript, 2001), using a slightly different approach, showed estimates of export production to be very sensitive to the choice of the primary production forcing data set. Basin-scale means of export production (and the respective export ratio, ER) ranged between 0.9 and 2.9 $\mathrm{GT} \mathrm{C} \mathrm{yr}^{-1}$ (equivalent to an $\mathrm{ER}=0.07-0.31$ ). The fraction of shallow remineralization was better constrained and showed a relationship with the depth of winter-time mixing, which for extratropical regions explained $92 \%$ of the variation of this fraction. Remineralization above the winter mixed layer depth was up to $62 \%$ of export production in the North Atlantic subarctic province.

[7] The overall aim of this paper is to describe the relative importance and the regional distribution of (a) shallow POC remineralization and (b) the $\mathrm{CaCO}_{3}$ balance (production and shallow dissolution) for the adjustment of the effective carbon flux (section 4). For this purpose, the empirical relationship between flux ratios of organic to inorganic carbon (POC:PIC flux ratio; "rain ratio") from particle interceptor traps deployed in the Atlantic Ocean during the JGOFS decade [SCOR, 1990], and water depth is developed (section 3.1). This empirical relationship is evaluated by comparison with independent data. In particular, the POC:PIC export ratio (section 3.2), the vertical change of the POC:PIC ratio (section 3.4), and of the PIC flux (section 3.3 ) in the Atlantic are discussed during this comparison. In the following sections a short description of the data sets used and a definition of some fundamental terms are given.

\section{Material and Methods}

\subsection{Data Sets, Depths Levels of Reference, Basin Scale Integration}

[8] Three-dimensional data sets of the organic carbon flux in the Atlantic Ocean are adopted from the study of Koeve (submitted manuscript, 2001). In that study a suit of eight comparative data sets of particulate organic carbon fluxes in the ocean was computed from maps of primary production [Antoine et al., 1996; Behrenfeld and Falkowski, 1997] and $J$-PP- $Z$ flux functions. $J$-PP-Z fits were based on local estimates of primary production derived from the global primary production maps and $\mathrm{Th}^{230}$-corrected [Scholten et al., 2001] POC flux observations made in the Atlantic Ocean in the 1990s as part of the JGOFS program [Antia et al., 2001]. A data set of POC:PIC flux ratios from particle flux studies in the Atlantic is also taken from the latter study. A detailed reference to the original particle flux data sets is given in the work by Antia et al. [2001] (their Table 1).

[9] This study focuses on carbon fluxes at two depth boundaries. Export production of particulate organic carbon $\left(\mathrm{JPOC}_{\text {exp }}\right)$ and particulate inorganic carbon $\left(\mathrm{JPIC}_{\text {exp }}\right)$ is the flux of POC and PIC across $Z_{\text {exp }}$. Operationally, and for the sake of easy comparison with published model results, $Z_{\text {exp }}$ is defined as $Z=125 \mathrm{~m}$ in this study. The carbon flux into 
Table 1. Empirical Relationships Between Flux Organic Particles $(J)$, Primary Production (PP), and Trap Deployment Depths $(Z)^{\mathrm{a}}$

\begin{tabular}{|c|c|c|c|c|c|c|c|c|}
\hline \multirow[t]{2}{*}{ Data set } & \multirow[t]{2}{*}{ Method $^{\mathrm{b}}$} & \multicolumn{3}{|c|}{ Parameter $^{\mathrm{c}}$} & \multicolumn{3}{|c|}{ Regression Analysis ${ }^{\mathrm{d}}$} & \multirow[t]{2}{*}{$n$} \\
\hline & & $a$ & $b$ & $c$ & $m$ & AA & $r^{2}$ & \\
\hline \multicolumn{9}{|c|}{$J_{c}$ Versus $J_{i}$} \\
\hline AM96 & linear & 1.69 & -0.98 & 1.11 & 1.008 & -0.005 & 0.410 & 24 \\
\hline BF97 & linear & 1.47 & -0.92 & 0.82 & 1.010 & 0.001 & 0.428 & 24 \\
\hline \multicolumn{9}{|c|}{$\ln \left(J_{c}\right)$ Versus $\ln \left(J_{i}\right)$} \\
\hline AM96 & $\log$ & 1.29 & -0.99 & 7.69 & 0.993 & -0.007 & 0.696 & 24 \\
\hline BF97 & $\log$ & 0.77 & -1.00 & 62.2 & 0.998 & 0.002 & 0.696 & 24 \\
\hline \multicolumn{9}{|c|}{$J_{c}$ Versus $J_{i}$} \\
\hline AM96 & linear & 1.55 & -0.72 & 0.30 & 0.992 & 0.008 & 0.791 & 23 \\
\hline BF97 & linear & 0.97 & -0.74 & 3.00 & 0.993 & 0.005 & 0.790 & 23 \\
\hline \multicolumn{9}{|c|}{$\ln \left(J_{c}\right)$ Versus $\ln \left(J_{i}\right)$} \\
\hline AM96 & $\log$ & 1.19 & -0.89 & 5.47 & 1.003 & -0.006 & 0.762 & 23 \\
\hline BF97 & $\log$ & 0.64 & -0.92 & 63.4 & 1.007 & 0.006 & 0.756 & 23 \\
\hline
\end{tabular}

${ }^{\mathrm{a}}$ These empirical relationships are established for primary production [Antoine et al., 1996; Behrenfeld and Falkowski, 1997] and particle flux [Antia et al., 2001] data sets from the Atlantic ocean (from Koeve, (submitted manuscript, 2001); modified).

${ }^{\mathrm{b}}$ Linear: linear optimization; log: logarithmic optimization.

${ }^{\mathrm{c}}$ The parameters of the exponential function $J_{c}=c \mathrm{PP}^{a} Z^{b}$ (equation (1)).

${ }^{\mathrm{d}}$ Model II linear regression analysis of $J_{c}$ versus $J_{i}$ (linear optimization) or $\ln \left(J_{c}\right)$ versus $\ln \left(J_{i}\right)$ (logarithmic optimization); $m=$ slope; AA $=y$-intercept; $J_{i}$ are Th-corrected POC fluxes at depth $Z_{i} ; \mathrm{J}_{c}$ are calculated POC fluxes (equation (1)) at depth $Z_{i}$ and primary production $\mathrm{PP}_{i}$; for details refer to the work of Koeve (submitted manuscript, 2001).

water masses which are isolated from exchange with the atmosphere on decadal to centennial timescales is referred to as carbon sequestration. It is distinguished between organic carbon sequestration $\left(\mathrm{JPOC}_{\text {sequ }}\right)$ and inorganic carbon sequestration $\left(\mathrm{JPIC}_{\text {sequ }}\right)$. The reference depth of carbon sequestration, $Z_{\text {sequ }}$, is estimated from the seasonal maximum depth of mixing $\left(Z_{\mathrm{wml}}\right)$. If, like in the tropics, $Z_{\mathrm{wml}}$ is shallower than $125 \mathrm{~m}, Z_{\text {sequ }}$ is set to $125 \mathrm{~m}$. This is a rough approximation of the depth of the lower boundary of the equatorial undercurrent, which forms the source water mass for equatorial upwelling. The estimation of the annual maximum depth of mixing is based on monthly resolving climatologies of temperature and salinity (NODC World Ocean Atlas, 1994; Monterey and Levitus, 1997). The mixed layer depth is defined as the change in density with respect to the surface by $0.125 \mathrm{~kg} \mathrm{dm}^{-3}$. $\mathrm{JPOC}_{\text {exp }}$, $\mathrm{JPIC}_{\text {exp }}$, $\mathrm{JPOC}_{\text {sequ }}$, and $\mathrm{JPIC}_{\text {sequ }}$ are two-dimensional data sets with a resolution of $1^{\circ}$ latitude $\times 1^{\circ}$ longitude.

\subsection{Formal Description of Carbon Fluxes}

[10] Formally the depths dependence of the organic carbon flux $\mathrm{J}_{\mathrm{POC}}$ can be empirically described according to equation (1).

[11] Sets of parameters $a, b$, and $c$ (Table 1), which were determined for eight combinations of different PP- and particle flux data sets and fitting techniques, are taken from the study of Koeve (submitted manuscript, 2001). Empirical descriptions of PIC fluxes were not directly estimated from trap observations but by combining equation (1) with empirical fits of the POC:PIC flux ratio (RR) according to equation (2)

$$
\begin{gathered}
J_{\mathrm{POC}}=c \mathrm{PP}^{a} Z^{b} \\
J_{\mathrm{PIC}}=J_{\mathrm{POC}} / \mathrm{RR}
\end{gathered}
$$

[12] As will be discussed in the next section, RR can be described in various ways as a function of the trap deployment depth. For these empirical fits the full non-polar data set $(n=76)$ of Antia et al. [2001] is used. This data set combines observations $(n=24)$ for which the trapping efficiency has been estimated $\left(\mathrm{Th}^{230}\right.$-approach; Scholten et al. [2001]) and data sets for which no $\mathrm{Th}^{230}$ data were available. This procedure is justified by the observations that $\mathrm{Th}^{230}$ is not selectively trapped by organic or inorganic particles [Scholten et al., 2001]. Estimating $\mathrm{J}_{\mathrm{PIC}}$ according to equation (2) has the advantage that a larger and more representative data set can be used, however, at the expense of combining empirical relationships which are based on different data sets.

[13] $J_{\mathrm{POC}}, J_{\mathrm{PIC}}$, and RR are data sets on a three dimensional grid (latitude, longitude, depth). From $J_{\mathrm{POC}}, J_{\mathrm{PIC}}, \mathrm{RR}$, and $\psi$, the ratio of released $\mathrm{CO}_{2}$ :precipitated carbonate during $\mathrm{CaCO}_{3}$ precipitation [Frankignoulle et al., 1994; see section 4.3.], a property called the net carbon flux, $\mathrm{J}_{\text {net }}$, can be defined as the carbon export that drives a potential draw-down of $\mathrm{CO}_{2}$ from the atmosphere to the ocean (equation (3)). $J_{\text {net }}$ is defined on the same three dimensional grid as $\mathrm{J}_{\mathrm{POC}}$.

[14] Finally, $J_{\text {eff }}$, the effective carbon flux is defined as the value of $\mathrm{J}_{\text {net }}$ at $Z=Z_{\text {sequ }}$. This indicates that only the net flux of carbon across the sequestration depths, which is estimated from the annual maximum mixing depth (see section 2.1), is regarded as being really effective in driving a drawdown of $\mathrm{CO}_{2}$ from the atmosphere to the ocean.

[15] Like $\mathrm{JPOC}_{\text {sequ }}$ or $\mathrm{JPIC}_{\text {sequ }}, J_{\text {eff }}$ is a two dimensional data set on a latitude/longitude grid. In this study $J_{\text {eff }}$ will be calculated according to equation (4), where $\bar{\Psi}$ indicates an appropriately averaged value of $\psi$ (see section 4.3)

$$
\begin{gathered}
J_{\text {net }}=J_{\mathrm{POC}}-\Psi J_{\mathrm{PIC}} \\
J_{\text {eff }}=\mathrm{JPOC}_{\text {sequ }}-\bar{\Psi}_{\mathrm{JPIC}} \mathrm{sequ}_{\text {se }}
\end{gathered}
$$


Table 2. Abbreviations Used in This Study

\begin{tabular}{|c|c|c|}
\hline Term & Units & Remarks \\
\hline$Z_{\exp }$ & $\mathrm{m}$ & reference depth of export production, in this study $Z_{\exp }=125 \mathrm{~m}$ \\
\hline$Z_{\text {sequ }}$ & $\mathrm{m}$ & $\begin{array}{l}\text { reference depth of carbon sequestration (i.e., the export of carbon into water layers which do not exchange with } \\
\text { the atmosphere on timescales of }>1 \text { yr) }\end{array}$ \\
\hline$Z_{\mathrm{wml}}$ & $\mathrm{m}$ & $\begin{array}{l}\text { climatological depth of the seasonal maximum of the mixed layer, winter mixed layer; in seasonal systems } Z_{\mathrm{wml}} \\
\text { is a good approximation of } Z_{\text {sequ }}\end{array}$ \\
\hline $\mathrm{JPOC}_{\text {exp }}, \mathrm{JPOC}_{125}$ & $\mathrm{~g} \mathrm{C} \mathrm{m}^{-2} \mathrm{yr}^{-1}$ & $\begin{array}{l}\text { export production (also a measure of new carbon production); in this study } \mathrm{JPOC}_{125} \text {, the flux of particulate } \\
\text { organic carbon in } 125 \mathrm{~m} \text { depth is used as an approximation of } \mathrm{JPOC}_{\text {exp }}\end{array}$ \\
\hline $\mathrm{JPOC}_{\mathrm{s}}$ & $\mathrm{g} \mathrm{C} \mathrm{m}^{-2} \mathrm{yr}^{-1}$ & sequestration of organic carbon, i.e., the export of organic carbon across $Z_{\text {sequ }}$ \\
\hline $\mathrm{JPIC}_{125}$ & $\mathrm{~g} \mathrm{C} \mathrm{m}^{-2} \mathrm{yr}^{-1}$ & he export of particulate inorganic carbon across $Z_{\mathrm{ex}}$ \\
\hline $\mathrm{JPIC}_{\text {sequ }}$ & $\mathrm{g} \mathrm{C} \mathrm{m}^{-2} \mathrm{yr}^{-1}$ & the sequestration flux of particulate inorganic carbon across $Z_{\text {sequ }}$ \\
\hline$J_{\text {net }}$ & $\mathrm{g} \mathrm{C} \mathrm{m}^{-2} \mathrm{yr}^{-1}$ & t carbon flux, see \\
\hline$J_{\text {eff }}$ & $\mathrm{g} \mathrm{C} \mathrm{m}^{-2} \mathrm{yr}^{-1}$ & $\begin{array}{l}\text { effective carbon flux, the flux of carbon which is effective with respect to the steady state surface } p \mathrm{CO}_{2} ; J_{\text {eff }} \text { is } \\
J_{\text {net }} \text { across } Z_{\text {sequ }}\end{array}$ \\
\hline$\Psi$ & mol:mol & the ratio of released $\mathrm{CO}_{2}$ :precipitated $\mathrm{CaCO}_{3}$ during calcium carbonate formation \\
\hline$r_{\mathrm{R}-\mathrm{POC}_{\text {sequ }}}$ & mol:mol & $\begin{array}{l}\text { the fraction of export production of organic carbon, } \mathrm{JPOC}_{125} \text {, which is remineralized above } Z_{\text {sequ }} ; r_{\mathrm{R}-\mathrm{POC}_{\text {sequ }}}= \\
\left(\mathrm{JPOC}_{125}-\mathrm{JPOC}_{\text {sequ }}\right) / \mathrm{JPOC}_{125}\end{array}$ \\
\hline$r_{\mathrm{R}-\mathrm{PIC}_{\text {sequ }}}$ & mol:mol & $\begin{array}{l}\text { the fraction of export of particulate inorganic carbon, } \mathrm{JPIC}_{125} \text {, which is remineralized above } \mathrm{Z}_{\text {sequ }} ; r_{\mathrm{R}-\mathrm{POC}_{\text {sequ }}}= \\
\left(\mathrm{JPOC}_{125}-\mathrm{JPOC}_{\text {sequ }}\right) / \mathrm{JPOC}_{125}\end{array}$ \\
\hline $\mathrm{RR}_{\text {sequ }}$ & mol:mol & the POC:PIC ratio ("rain ratio") at $Z_{\text {sequ }}$ \\
\hline
\end{tabular}

[16] Abbreviations used in this study are summarized in Table 2. (model I) of RR over ln (Z) [Antia et al., 2001] (equation (5)) and an exponential fit (equation (6))

\section{POC:PIC Ratios}

\subsection{POC:PIC Flux Ratios From Particle}

\section{Flux Observations}

[17] Two functionalities of the vertical profile of the POC:PIC flux ratio (RR) are analyzed, a linear regression

$$
\begin{gathered}
\mathrm{RR}=d \ln (Z)+e \\
\mathrm{RR}=d Z^{e}
\end{gathered}
$$

[18] For the data from the Atlantic Ocean (Figure 1a) the best fits are $\mathrm{RR}=0.827( \pm 0.0683) \ln (\mathrm{Z})+7.34( \pm 0.504)$



Figure 1. Vertical distribution of the POC:PIC flux ratio and PIC fluxes in the North Atlantic. (a) POC:PIC flux ratio (RR). +: observations, $n=76$; Antia et al. [2001]. Solid line: exponential function, $\mathrm{RR}=64.3 \mathrm{Z}^{-0.56} ; r^{2}=0.693$ (this study). Dashed line: logarithmic fit, $\mathrm{RR}=7.34-0.827 \ln (Z) ; r^{2}=$ 0.664 (this study). (b, c) Distribution of the normalized $\left(\left(x_{\mathrm{i}}-\operatorname{mean}\left(x_{\mathrm{i}}\right)\right) / \operatorname{std}\left(x_{\mathrm{i}}\right)\right)$ and site independent relative vertical profile of $J_{\mathrm{PIC}}$, named $\left(J_{\mathrm{PIC}} / \mathrm{L}\right)^{*}$. Here $\mathrm{L}$ is a shortcut of the term $c \mathrm{PP}^{a}$ of equation $(1)$ and $b$ is the $z$-exponent of equation (1). (b) Estimates based on logarithmic RR-Z functions. Solid line: Antia et al. [2001]; $b=-0.68, \mathrm{RR}=7.39-0.83 \ln (Z)$; dashed line: this study; $b=-1, \mathrm{RR}=7.34-0.827$ $\ln (Z)$. (c) Estimates based on the exponential RR- $Z$ function $R R=64.3 Z^{-0.56}$ from this study. Solid line: $b=-1.0$; dashed line: $b=-0.7$. Note the artificial increase in $\left(J_{\mathrm{PIC}} / \mathrm{L}\right)^{*}$ in the deep ocean in Figure $1 \mathrm{~b}$. 
Table 3. Estimates of the POC:PIC Ratio of Production

\begin{tabular}{|c|c|c|c|c|c|}
\hline Scenario & Latitude & $\begin{array}{l}{\left[\mathrm{NO}_{3} / \mathrm{Si}(\mathrm{OH})_{4}\right]} \\
(\text { Winter })^{\mathrm{a}}\end{array}$ & $f_{\text {diatoms }}$ & $\begin{array}{l}\text { POC:PIC Ratio } \\
\text { of Production }\end{array}$ & Remarks \\
\hline 1 & $47^{\circ} \mathrm{N}$ & 2.6 & 0.38 & 2.9 & assuming a POC:PIC ratio of $6: 1$ during the diatom bloom ${ }^{b}$ \\
\hline 2 & $47^{\circ} \mathrm{N}$ & 2.6 & 0.38 & 4.0 & $\begin{array}{l}\text { like scenario } 1 \text {, but assuming a POC:PIC ratio of 9:1 during the } \\
\text { diatom bloom }\end{array}$ \\
\hline 3 & $60^{\circ}-62^{\circ} \mathrm{N}$ & 2.0 & 0.5 & 3.5 & $\begin{array}{l}\text { assuming summer nitrate depletion and the POC:PIC ratio during } \\
\text { the diatom bloom of } 6: 1\end{array}$ \\
\hline 4 & $60^{\circ}-62^{\circ} \mathrm{N}$ & 2.0 & 0.64 & 4.2 & $\begin{array}{l}\text { assuming summer silicate depletion, }{ }^{\mathrm{d}} \text { summer nitrate concentra- } \\
\text { tions }{ }^{\mathrm{e}} \text { of about } 3 \mu \mathrm{mol} \mathrm{dm}{ }^{-3} \text {, and a contribution of coccolitho- } \\
\text { phorids to post spring bloom new production of } 100 \%\end{array}$ \\
\hline 5 & $60^{\circ}-62^{\circ} \mathrm{N}$ & 2.0 & 0.64 & 5.1 & $\begin{array}{l}\text { assuming summer silicate depletion, d summer nitrate concentra- } \\
\text { tions of about } 3 \mu \mathrm{mol} \mathrm{dm} \mathrm{dm}^{-3} \text {, and a contribution of coccolitho- } \\
\text { phorids to post spring bloom new production of } 50 \%\end{array}$ \\
\hline \multicolumn{6}{|c|}{ From Particle Flux Algorithms } \\
\hline $65^{\circ} \mathrm{S}-65^{\circ} \mathrm{N}$ & & & & 3.4 & $\mathrm{RR}_{125}, \mathrm{RR}-\ln (Z)$ fit; from ${ }^{\mathrm{f}, \mathrm{g}}$ \\
\hline $65^{\circ} \mathrm{S}-65^{\circ} \mathrm{N}$ & & & & 4.4 & $\mathrm{RR}_{125}$, exponential fit of $\mathrm{RR}$; from ${ }^{\mathrm{f}}$ \\
\hline \multicolumn{6}{|c|}{ From Seasonal Changes of $\mathrm{CO}_{2}$, Alkalinity, and Nitrate } \\
\hline NAST $\left(27^{\circ}-42^{\circ} \mathrm{N}\right)$ & & & & 3.9 & province means of data presented in Figure 2; from ${ }^{\mathrm{f}}$ \\
\hline $\operatorname{NADR}\left(42^{\circ}-55^{\circ} \mathrm{N}\right)$ & & & & 4.3 & -"-; from ${ }^{\mathrm{f}}$ \\
\hline SARC/ARCT $\left(>55^{\circ} \mathrm{N}\right)$ & & & & & -“-; from ${ }^{\mathrm{f}}$ \\
\hline north of $40^{\circ} \mathrm{N}$ & & & & $5.3-5.9$ & from ${ }^{\mathrm{h}}$ \\
\hline $40^{\circ} \mathrm{S}-40^{\circ} \mathrm{N}$ & & & & $4.9-5.1$ & from $^{\mathrm{h}}$ \\
\hline & & & & $(4.2-4.4)$ & $\begin{array}{l}\text { ratio in brackets is calculated for data without the warming period: } \\
\text { whole year scaling factor used by }\end{array}$ \\
\hline south of $40^{\circ} \mathrm{S}$ & & & & $8.9-12.1$ & from $^{\mathrm{h}}$ \\
\hline $\begin{array}{l}\text { a Koeve [2001]. } \\
{ }^{\mathrm{b}} \text { Robertson et al. }[1 \\
{ }^{\mathrm{c}} \text { Takahashi et al. }[1 \\
{ }^{\mathrm{d}} \text { Veldhuis et al. }[199 \\
{ }^{\mathrm{d}} \text { Sambrotto et al. }[1 \\
{ }^{\mathrm{e}} \text { This study. } \\
{ }^{\mathrm{g}} \text { Antia et al. }[2001] . \\
{ }^{\mathrm{h}} \text { Lee [2001]. }\end{array}$ & $\begin{array}{l}\text { 994]. } \\
\text { 990] as cited } \\
\text { 93]. } \\
\text { 993]. }\end{array}$ & the study by $R o$ & rtson et a & [1994]. & \\
\hline
\end{tabular}

and $\mathrm{RR}=64.3 \mathrm{Z}^{-0.56}[\ln (\mathrm{RR})=-0.557( \pm 0.0516) \ln (\mathrm{Z})+$ $\ln (4.16 \pm 0.381)]$, respectively. The statistics for both functions are quite similar. Model-II regressions [Sokal and Rohlf, 1995] of the predicted versus the observed flux ratios yield $r^{2}$ values of 0.664 (RR-ln Z) and 0.693 (exponential fit). A major difference, however, shows up, when JPIC is estimated from JPOC and the POC:PIC ratio according to equation (2). In the case of the RR-ln Z function JPIC decreases only down to about $1500 \mathrm{~m}$ but increases again in the deep ocean (Figure 1b). This unprecedented increase of the PIC flux is not seen if the POC:PIC ratio is estimated from the exponential fit. Here JPIC continuously decreases with depth (Figure 1c).

\subsection{The POC:PIC Ratio of Export Production}

[19] In this section the POC:PIC ratio of export production $\left(R_{\text {exp }}\right)$ is estimated based on the particle flux algorithms discussed above (section 3.2.1), an analysis of data from process studies in the North Atlantic (section 3.2.2), and finally, based on climatological data (section 3.2.3).

\subsubsection{Estimates From Particle Flux Algorithms}

[20] Using the exponential RR-Z function, a mean POC:PIC flux ratio in $125 \mathrm{~m}$ depth, $\mathrm{RR}_{125}$, of 4.37 is estimated. Propagating the standard errors of the parameters $\mathrm{d}$ and e (see section 3.1) through the computation yields a range of $2.33-8.21$ for $R_{125}$. The logarithmic fit suggests an POC:PIC export ratio of $3.35( \pm 0.834)$.

\subsubsection{Estimates From Field Studies in the North Atlantic}

[21] Few local estimates of the POC:PIC ratio of production have been published to compare the estimates from the particle flux algorithm with. In the following I will combine estimates of the POC:PIC ratio of net carbon production during a coccolithophorid bloom in the subpolar North Atlantic and from spring bloom studies in the temperate and subpolar North Atlantic [Robertson et al., 1994] with winter-time nutrient estimates [Koeve, 2001] to compute the range of the annually integrated POC:PIC ratio of new production in this region. Robertson et al. [1994] estimated the POC:PIC ratio from the relative change of potential alkalinity $\left(A_{\text {pot }}=A_{t}+\mathrm{NO}_{3}\right.$; Fiadeiro $\left.[1980]\right)$ and total $\mathrm{CO}_{2}$ over time. They found POC:PIC ratios of production of $1: 1$ for a coccolithophorid bloom and 6:1 during a diatom spring bloom period. The annual mean POC:PIC ratio depends on the relative importance of diatoms, coccolithophorids, and non-calcifying flagellates (e.g., Phaeozystis) for annual new production. A first order estimate of the quantitative role of diatoms can be achieved from wintertime $\mathrm{NO}_{3}: \mathrm{Si}(\mathrm{OH})_{4}$ ratios and the mean nitrate:silicate uptake ratio of diatoms (about 1:1; Richards, 1958; Brzezinski [1985]). The decrease of wintertime $\mathrm{NO}_{3}: \mathrm{Si}(\mathrm{OH})_{4}$ ratios from 2.8 to 2 between $40^{\circ} \mathrm{N}$ and $60^{\circ} \mathrm{N}$ along $20^{\circ} \mathrm{W}$ [Koeve, 2001], converts to an increase of the relative contribution of diatoms to new carbon production from about $35-38 \%$ (at $40^{\circ} \mathrm{N}$ to $47^{\circ} \mathrm{N}$ ) to $50-64 \%$ at $60^{\circ} \mathrm{N}$ ( $f_{\text {diatoms }}$ in Table 3$)$. How this ratio 
translates to the annual POC:PIC ratio, depends on whether all post-diatom bloom nitrate is taken up over the growth season and which share coccolithophorids can take. If one assumes that all post-diatom bloom nitrate uptake is by coccolithophorids (with a POC:PIC ratio of 1:1, Robertson et al., 1994), an annual POC:PIC ratio of net production between 2.9 and 4.0 is calculated for $47^{\circ} \mathrm{N}$, and slightly higher values are found for $60^{\circ} \mathrm{N}(3.5-4.2)$ (Table 3).

[22] These are minimum estimates for the POC:PIC ratio of production, since new production by non-calcifying flagellates is ignored and since no correction for air sea exchange is taken into account. New production by noncalcifying phytoplankton after the diatom spring bloom will reduce the pool of nitrate and phosphate available for coccolithophorids and thereby increase the annual POC:PIC production ratio. Air-sea exchange, which was prominent (up to $25 \%$ of the apparent total $\mathrm{CO}_{2}$ drawdown over 2-3 months) when the $\mathrm{C}: \mathrm{N}$ ratios of new production was calculated from seasonal changes of total $\mathrm{CO}_{2}$ and nitrate [Körtzinger et al., 2001a], will act into the same direction. In particular, it will increase the POC:PIC ratio during the diatom spring bloom, since air-sea $p \mathrm{CO}_{2}$ gradients and wind speed are higher during that season. Currently few process studies are available to describe the temporal and regional distribution of the POC:PIC export ratio in more detail. In the following section, I therefore present a first order estimate of the large scale distribution of the annual $R_{\text {exp }}$ in the Atlantic from a climatological perspective.

\subsubsection{Large Scale Distribution of $\mathbf{R R}_{\text {exp }}$}

[23] In temperate and subarctic waters the surface mixed layer POC:PIC ratio of production $\left(\mathrm{RR}_{\mathrm{ML}}\right)$ may be derived from the seasonal changes in salinity normalized total alkalinity and nitrate in the surface mixed layer and the $\mathrm{C}: \mathrm{N}$ ratio of new production (equation (7)). Operationally it is assumed here that new carbon production (NP) which is exported via particles can be estimated from the seasonal drawdown of nitrate by multiplying with a constant $\mathrm{C}: \mathrm{N}$ ratio of 6.625 [Redfield et al., 1963; Körtzinger et al., 2001a]. $\mathrm{CaCO}_{3}$ production $\left(P_{\mathrm{CaCO}_{3}}\right)$ is estimated from seasonal changes of alkalinity and nitrate according to the concept of potential alkalinity (see section 3.2.2). In this section, however, data from climatologies of nitrate, alkalinity, and salinity are used to compute $\mathrm{RR}_{\mathrm{ML}}$. Details of the computation are given in Appendix A. It is assumed that the mixed layer POC:PIC ratio is an appropriate proxy of the export POC:PIC ratio $\mathrm{RR}_{\exp }$ (i.e., $\mathrm{RR}_{\mathrm{exp}} \approx \mathrm{RR}_{\mathrm{ML}}$ )

$$
\begin{aligned}
\mathrm{RR}_{\mathrm{ML}} & =\frac{\mathrm{NP}}{\mathrm{P}_{\mathrm{CaCO}_{3}}}=\frac{\Delta \mathrm{NO}_{3} \times \mathrm{C} / \mathrm{N}}{\left(\Delta A_{t}+\Delta \mathrm{NO}_{3}\right) / 2} \\
& =\frac{\Delta \mathrm{NO}_{3}}{\left(\Delta A_{t}+\Delta \mathrm{NO}_{3}\right)} \times(\mathrm{C} / \mathrm{N}) \times 2
\end{aligned}
$$

[24] In the subtropics and tropics the seasonal approach cannot be used since seasonal gradients of alkalinity and nitrate vanish. As a substitute I estimate $\mathrm{RR}_{\text {exp }}$ from particle interceptor trap measurements [Lohrenz et al., 1992] at the Bermuda Time Series Station (BATS). RR $R_{\exp }$ at BATS is estimated to be 4.1-4.5 (see Appendix A for details).

[25] The major feature of the estimate of $\mathrm{RR}_{\exp }$ in temperate and subarctic North Atlantic is a polarward gradient, overlaid by a weaker east-west gradient with maximal values in the North East Atlantic (Figure 2). Minima of $\mathrm{RR}_{\text {exp }}$ are seen at the boundary between the temperate and the subtropical domains $\left(35^{\circ} \mathrm{N}\right.$ and $\left.\mathrm{S}\right)$ which is also the boundary between estimates from the seasonal change of potential alkalinity and estimates from shallow traps at BATS. The intensity of these minima is subject to the choice of the $\mathrm{C}: \mathrm{N}$ ratio of sinking particles (see equation (7)) and the choice of the geographic position of the boundary itself. Province mean values of $R R_{\exp }$ in the temperate and subarctic North Atlantic increase northward from 3.9 (NAST) to 6.1 (SARC/ARCT) (Table 3), the weighted mean for the temperate and subarctic North Atlantic (all three provinces) is 4.37 , which compares well with $\mathrm{RR}_{125}$ from the exponential $\mathrm{RR}-Z$ fit.

[26] Recently, Lee [2001] presented an analysis of the global net community production and the global $\mathrm{CaCO}_{3}$ production based on an analysis of the annual cycle of surface water total $\mathrm{CO}_{2}$ and alkalinity. They estimated organic carbon:inorganic carbon uptake ratios of 5.3-5.9 for the temperate and subarctic Atlantic $\left(40^{\circ} \mathrm{N}-70^{\circ} \mathrm{N}\right)$, slightly lower values for the subtropical and tropical band $\left(40^{\circ} \mathrm{S}-40^{\circ} \mathrm{N}: \mathrm{RR}_{\mathrm{ML}}=4.9-5.1\right)$ but significantly higher values for the southern Ocean (Atlantic south of $40^{\circ} \mathrm{S}$ : $\left.\mathrm{RR}_{\mathrm{ML}}=8.9-12.1\right)$. Their Atlantic integral value was $6.1-$ 6.9. The estimate of net carbon production from seasonal changes in total $\mathrm{CO}_{2}$ [Lee, 2001] does not differentiate whether carbon is stored and exported as particles or as DOC. One might use the difference between the $R R_{M L}$ estimate from this study $(4.2-4.37)$ and those from the study of Lee [2001] to approximate that on the mean 39$58 \%$ of net carbon production in the Atlantic is channeled through a seasonally accumulating pool of DOC [Kähler and Koeve, 2001] which eventually is exported from the mixed layer during winter time convection [Carlson et al., 1994] but is respired above the winter mixed layer depth or on shallow isopycnals [Doval and Hansell, 2000] and hence does contribute little to carbon sequestration. Regarding the involved uncertainties (about $\pm 30 \%$ for the estimates based on data from the work of Lee, 2001), both studies support that the organic:inorganic carbon ratio of export production in the Atlantic is close to the canonical value of about 4-5 [Li et al., 1969; Broecker and Peng, 1982].

\subsubsection{Polarward Increase of $\mathbf{R R}_{\text {exp }}$}

[27] Estimates from this study (sections 3.2.2 and 3.2.3) suggest a polarward increase of $R_{\text {exp }}$ in the Atlantic Ocean. This sounds counterintuitive since the subpolar North Atlantic, in particular waters south of Iceland, is well known for the frequent occurrence of coccolithophorid blooms [Holligan and Balch, 1991; Holligan et al., 1993; Fernandez et al., 1993; Balch et al., 1996] and one might therefore expect the POC:PIC ratio of export production to be low.

[28] In section 3.2.2 (and Table 3) it was shown that the northward increase of $\mathrm{RR}_{\exp }$ goes along with increases in the contribution of diatoms to annual new production, which were driven by a decrease of the winter $\mathrm{NO}_{3}: \mathrm{Si}(\mathrm{OH})_{4}$ ratio. Because of an overall deepening of the winter mixed layer from the subtropics to the subarctic North Atlantic winter time nutrient concentrations increase polarward [Glover and Brewer, 1988; Koeve, 2001]. Coccolithophorid blooms, i.e., 


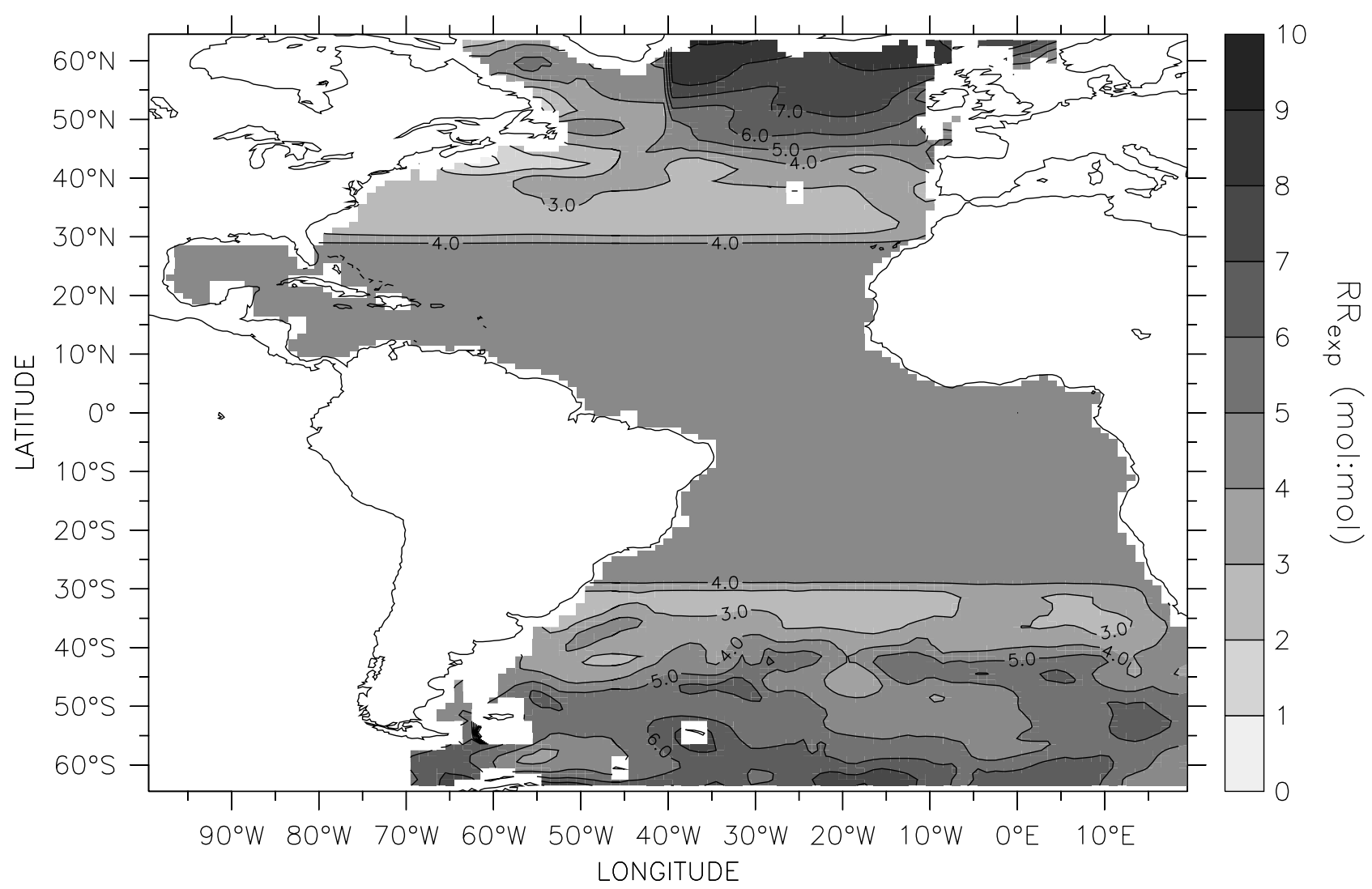

Figure 2. Regional distribution of $R R_{\text {exp }}$ in the Atlantic Ocean. North of $35^{\circ} \mathrm{N}$ and south of $35^{\circ} \mathrm{S}, \mathrm{RR}_{\mathrm{exp}}$ is estimated from seasonal changes of potential alkalinity and nitrate. In the subtropical bands $\left(10^{\circ}-\right.$ $35^{\circ} \mathrm{N}, 10^{\circ}-35^{\circ} \mathrm{S}$ ) an estimate based on particle interceptor trap measurements at the Bermuda Time series Station (BATS) is assumed as a constant value. In the tropical band $\left(10^{\circ} \mathrm{S}-10^{\circ} \mathrm{N}\right)$ an export flux ratio of 4.37 is used. For details see section 3.2.3 and the Appendix A.

high absolute rates of PIC production and the biomass of coccolithophorids, require high nitrate stocks after the diatom bloom has ended because of the depletion of silicate. Postdiatom bloom nitrate concentrations in the euphotic zone can be calculated to the first order from winter nitrate and silicate concentrations according to $\mathrm{NO}_{3 \text { (post) }}=\mathrm{NO}_{3 \text { (winter) }}$ $\mathrm{Si}(\mathrm{OH})_{4 \text { (winter) }} \times(\mathrm{N} / \mathrm{Si})_{\text {uptake ratio }}$ (like in section 3.2.2. a mean $(\mathrm{N} / \mathrm{Si})_{\text {uptake ratio }}=1$ is assumed). Between $41^{\circ} \mathrm{N}$ and $59^{\circ} \mathrm{N}$, the post-diatom bloom nitrate concentration increases from 2.9 to $6.5 \mathrm{mmol} \mathrm{N} \mathrm{m}^{-3}$ at $59^{\circ} \mathrm{N}$ (calculated after data presented by Koeve [2001]). Simply by the availability of nitrate after the diatom bloom has ended there is an increasing potential for coccolithophorid blooms and $\mathrm{CaCO}_{3}$ production toward the north. At the same time $f_{\text {diatom }}$ (Table 3 ) and hence the POC:PIC production ratio increases northward. It is concluded, that the seemingly contradiction between increasing $R_{\text {exp }}$ toward the northern North Atlantic (this study) and observations of huge coccolithophorid blooms south of Iceland can be explained by the north-south distribution of relative and absolute rates at which nitrate and silicate are supplied to the surface ocean during winter mixing.

\subsection{Evaluation of the Change of the PIC Flux Over Depth}

[29] One of the oldest paradigms in oceanography states that pelagic $\mathrm{CaCO}_{3}$ dissolves exclusively below the lyso- cline and, due to high sinking speeds and slow dissolution, particularly within the sediments. Major evidence for this view is from the observation that vast areas and depth ranges of the ocean show a low corrosity for $\mathrm{CaCO}_{3}$ (i.e., saturation state $\Omega>0.8$ ), and from experimental studies of $\mathrm{CaCO}_{3}$ dissolution [Peterson, 1966; Keir, 1980]. Along the same line, sediment trap data suggested that the PIC flux does not decrease significantly below $1000 \mathrm{~m}$ depth [Tsunogai and Noriki, 1991; Milliman, 1993]. This is accentuated in the North Atlantic [Honjo, 1990; Honjo and Manganini, 1993], where the depth of the calcite-lysocline is found at about $4000-4500 \mathrm{~m}$.

[30] Combining the $J$-PP-Z functions of Koeve (submitted manuscript, 2001) (Table 1) and the POC:PIC ratio fits from this study allows to estimate changes in the PIC fluxes with depth. All parameter sets predict a significant decrease of the PIC flux in the upper $1000 \mathrm{~m}$. The ratio of PIC fluxes in 125 and $1000 \mathrm{~m}, \mathrm{JPIC}_{125} / \mathrm{JPIC}_{1000}$, varies between 1.4 and 2.5 (exponential RR fit; Figure 1c), indicating that $31-59 \%$ of the PIC export dissolves in the upper $1000 \mathrm{~m}$. There are few data from (drifting) shallow sediment traps to compare this estimate with. The experiment of Martin et al. [1993] during the North Atlantic Bloom Experiment (NABE), in which floating VERTEX-type traps were deployed between 150 and $2000 \mathrm{~m}$ over the course of the spring bloom (6 weeks), supports a similar decrease in PIC fluxes of about 
Table 4. Estimates of the POC:PIC Ratio of Remineralization

\begin{tabular}{|c|c|c|c|c|c|}
\hline & Isopycnal & $\Delta \mathrm{O}_{2} / \Delta \mathrm{Ca}^{\mathrm{a}}$ & $\Delta \mathrm{O}_{2} / \Delta \Sigma \mathrm{CO}_{2}$ & $\mathrm{RR}_{\text {remin }}^{\mathrm{b}}$ & \\
\hline $\begin{array}{l}\text { North Atlantic } \\
\text { North Atlantic } \\
\text { South Atlantic } \\
\text { South Atlantic } \\
\end{array}$ & $\begin{array}{l}27.0 \\
27.2 \\
27.0 \\
27.2 \\
\end{array}$ & $\begin{array}{l}-11 \pm 3 \\
-22 \pm 7 \\
-20 \pm 5 \\
-24 \pm 11\end{array}$ & $\begin{array}{l}-1.3 \pm 0.1 \\
-1.3 \pm 0.1 \\
-1.3 \pm 0.1 \\
-1.3 \pm 0.1\end{array}$ & $\begin{array}{l}7.5 \pm 3.0 \\
16.0 \pm 6.8 \\
14.4 \pm 4.7 \\
17.5 \pm 9.4 \\
\end{array}$ & 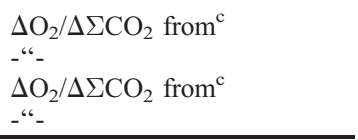 \\
\hline Depth Range, $\mathrm{m}$ & Isopycnal & $Z$-exponent of $J$-PP- $Z$ Function (b) ${ }^{\mathrm{d}}$ & & & \\
\hline $250-700$ & 27.0 & $\begin{array}{l}-0.7 \\
-1.0\end{array}$ & & $\begin{array}{l}8.3-14.7 \\
3.8-6.7\end{array}$ & $\begin{array}{l}\text { for estimates based on the } \\
\text { exponential fit of RR over Z } \\
\text { from }^{\mathrm{e}}\end{array}$ \\
\hline $450-1000$ & 27.2 & $\begin{array}{l}-0.7 \\
-1.0\end{array}$ & & $\begin{array}{l}6.8-10.6 \\
3.1-4.8\end{array}$ & -“- \\
\hline $250-700$ & 27.0 & -0.7 & & $1.2-2.1$ & $\begin{array}{l}\text { for estimates based on the RR- } \\
\operatorname{lnZ} \text { fit; from }\end{array}$ \\
\hline $450-1000$ & 27.2 & $\begin{array}{l}-1.0 \\
-0.7 \\
-1.0\end{array}$ & & $\begin{array}{l}1.4-2.4 \\
0.9-1.6 \\
1.1-1.8\end{array}$ & -“- \\
\hline
\end{tabular}

${ }^{a}$ For $\Delta \mathrm{O}_{2} / \Delta \mathrm{Ca}$, the term $\Delta \mathrm{Ca}$ is estimated according to the concept of potential alkalinity from the change in total alkalinity $(\Delta \mathrm{TA})$ and the change in nitrate $\left(\Delta \mathrm{NO}_{3}\right)$ according to $\Delta \mathrm{Ca}=\left(\Delta \mathrm{TA}+\Delta \mathrm{NO}_{3}\right) / 2$, Takahashi et al. [1985].

${ }^{\mathrm{b}} \mathrm{RR}_{\mathrm{remin}}=\Delta \Sigma \mathrm{CO}_{2} / \Delta \mathrm{Ca}-1$.

${ }^{\mathrm{c}}$ Körtzinger et al. [2001b].

${ }^{\mathrm{d}}$ Koeve (submitted manuscript, 2001).

${ }^{\mathrm{e}}$ This study.

$50 \%$ in the upper $1000 \mathrm{~m}$. Milliman et al. [1999] summarize the currently available evidence for shallow PIC dissolution and suggest that on average about $59 \%$ of the global carbonate production dissolves in the upper $1000 \mathrm{~m}$.

[31] It is in this depth horizon where organic carbon fluxes change most rapidly; the ratio of the organic carbon fluxes at 125 and $1000 \mathrm{~m}, \mathrm{JPOC}_{125} / \mathrm{JPOC}_{1000}$, varies between 4.5 and 8.1 , suggesting an organic carbon remineralization of $77-$ $88 \%$ within the upper $1000 \mathrm{~m}$. A possible mechanism driving $\mathrm{CaCO}_{3}$ dissolution above the lysocline is dissolution within "microenvironments" of high $p \mathrm{CO}_{2}$, derived from intense remineralization of organic carbon. Here, the concentration of $\mathrm{CO}_{3}^{2-}$ could decrease locally such that the concentration product of $\mathrm{CO}_{3}^{2-}$ and $\mathrm{Ca}^{2+}$ becomes smaller than the dissolution product against the dissolution of $\mathrm{CaCO}_{3}$. Such microenvironments might be either fecal pellets or aggregates of particulate organic matter. Organic aggregates [Riley, 1963; "marine snow"], which are a very important vehicle for the transport of biogenic matter into the deep ocean [Fowler and Knauer, 1986], are known as sites of active metabolism [Pomeroy and Johannes, 1968; Turley, 1992] and may be sites of shallow and microscale $\mathrm{CaCO}_{3}$ dissolution. The build up of a $p \mathrm{CO}_{2}$ (and $\mathrm{CO}_{3}^{2-}$ ) gradient between the aggregate and the surrounding water would be a necessary prerequisite of a significant $\mathrm{CaCO}_{3}$ dissolution in such aggregates. There is, however, conflicting evidence whether the degradation products (nutrients, $\mathrm{CO}_{2}$, oxygen debt) accumulate in aggregates [Brzezinski et al., 1997] or not [Ploug and Joergensen, 1999]. Another possible process to promote shallow PIC remineralization is dissolution in the guts of zooplankton [Takahashi, 1975]. Critical to this issue is, whether the $\mathrm{pH}$ of grazer guts is high [Honjo and Roman, 1978] or may, like in the case of starved copepods [Pond et al., 1995], be low enough to support $\mathrm{CaCO}_{3}$ dissolution. Recently, laboratory feeding experiments comparing the amount of ingested and egested coccolithophors, indicated dissolution rates of 50\% and more [Harris, 1994]. Milliman et al. [1999] provide a detailed and thorough overview of the current evidence for and the processes involved in shallow $\mathrm{CaCO}_{3}$ dissolution.

[32] Below $1000 \mathrm{~m}$, PIC dissolution decreases with increasing depth $\left(7.5-10.5 \%\right.$ of $\mathrm{JPIC}_{125}$ between 1000 and $2000 \mathrm{~m}$, and 7-8\% between 2000 and $4000 \mathrm{~m}$ ). Overall, 46$77 \%$ of $\mathrm{JPIC}_{125}$ dissolves above $4000 \mathrm{~m}$ depth. This is in good agreement with the finding of Archer [1996] and Archer et al. [2000a] that the global production rate of $\mathrm{CaCO}_{3}$ required by the ocean surface/deep alkalinity contrast [Li et al., 1969] is higher by roughly a factor of three than the average $\mathrm{CaCO}_{3}$ rain rate to the seafloor required by sediment diagenesis models of Archer [1996], hence about 2/3 of calcium carbonate production dissolves in the water column.

\subsection{POC:PIC Ratio of Remineralization}

[33] In this section the organic carbon:inorganic carbon remineralization ratio $\left(R_{\text {remin }}\right)$ is estimated from the change of POC and PIC particle fluxes over depth, and from an analysis of the along-isopycnal change of the degradation products of POC remineralization and PIC dissolution in the interior of the ocean.

[34] In the latter case, $R_{\text {remin }}$ is calculated from $R_{\text {remin }}=$ $\Delta \Sigma \mathrm{CO}_{2} / \Delta \mathrm{Ca}-1$ were $\mathrm{Ca}$ is computed from total alkalinity (TA) and nitrate, according to $\mathrm{Ca}=\left(\mathrm{TA}+\mathrm{NO}_{3}\right) / 2 . \Delta \Sigma \mathrm{CO}_{2}$ and $\Delta \mathrm{Ca}$ are estimated from regression slopes versus oxygen $\left(\Delta \mathrm{O}_{2}\right)$ on isopycnals or neutral surfaces. I use $\Delta \mathrm{O}_{2} / \Delta \mathrm{Ca}$ ratios estimated by Takahashi et al. [1985] for shallow isopycnals just below the permanent thermocline (sigmatheta density levels $\sigma_{\theta}=27.0$ and $\sigma_{\theta}=27.2$; Table 4). Takahashi et al. [1985] report $\Delta \mathrm{O}_{2} / \Delta \Sigma \mathrm{CO}_{2}$ ratios, which range between $-1.7 \pm 0.1$ and $-2 \pm 0.1$. Their analysis, however, did not correct for the time history of the invasion of anthropogenic $\mathrm{CO}_{2}$ into the ocean [Takahashi et al., 1985]. The temporal change in anthropogenic $\mathrm{CO}_{2}$ in the atmosphere causes a slight increase over time in the initial $\mathrm{CO}_{2}$ concentration when a water mass is formed. If this effect is not taken into account, the $\Delta \Sigma \mathrm{CO}_{2}$ due to remineralization along an isopycnal is underestimated and the $\Delta \mathrm{O}_{2} / \Delta \Sigma \mathrm{CO}_{2}$ 
ratio of remineralization is overestimated. Correcting for the time history of anthropogenic $\mathrm{CO}_{2}$ invasion, Körtzinger et al. [2001b] estimate a $\Delta \mathrm{O}_{2} / \Delta \Sigma \mathrm{CO}_{2}$ ratio of $-1.3 \pm 0.1$ for isopycnals just beneath the permanent thermocline. $R_{\text {remin }}$ on shallow isopycnals, thereafter, is estimated to range between 7.5-16.0 (North Atlantic) and 14.4-17.5 (South Atlantic) (see Table 4). These are mean estimates for the given ocean basins within which the specified isopycnals are encountered over a broad depth range of 250-700 $\mathrm{m}\left(\sigma_{\theta}=\right.$ 27.0) and 450-1000 $\mathrm{m}\left(\sigma_{\theta}=27.2\right)$.

[35] Within this depth range mean $\mathrm{RR}_{\text {remin }}$ estimated from particle flux data (exponential RR- $Z$ relationship) range from 6.8 to 14.7 and 3.1 to 6.7 (Figure 3, thick lines) for values of the $Z$-exponent of the $J$-PP- $Z$ function of $b=-0.7$ and $b=-1.0$, respectively. This range of $b$-values was found to be representative for the particle flux data set used in this study (Table 1). If the $R_{\text {remin }}$ estimate is based on the RR-ln Z relationship (Figure 3, thin lines) much lower values are estimated $(0.9-2.4)$. Clearly $R_{\text {remin }}$ estimates from the exponential RR-Z relationship compare better with the $R_{\text {remin }}$ estimates from the isopycnal analysis than do those from the logarithmic RR-Z relationship. The difference between $R_{\text {remin }}$ estimates from the isopycnal analysis and from the exponential RR- $Z$ particle flux relationship may be attributed to remineralization of DOC, which has been found to be significant on shallow isopycnals [Doval and Hansell, 2000].

\subsection{POC:PIC Ratios: Some Conclusions}

[36] Two alternative mathematical functions with almost identical statistics can be used to represent the mean depth dependence of the POC:PIC ratio of particle flux in the Atlantic ocean (section 3.1). However, only one of the models, the exponential function $\mathrm{RR}=64.3 \mathrm{Z}^{-0.56}$, yields (a) a consistent vertical distribution of the PIC flux (sections 3.1 and 3.3 and Figure 1c), (b) POC:PIC ratios of remineralization which match the distribution of breakdown products of POC remineralization and PIC dissolution on shallow isopycnals (section 3.4, Figure 3 and Table 4), and (c) POC:PIC export ratios $\left(\mathrm{RR}_{\text {exp }}\right)$ which agree with basin scale means of $\mathrm{RR}_{\mathrm{ML}}$ estimates from seasonal changes of nutrients and alkalinity (section 3.2). On the contrary, the logarithmic RR-Z relationship which was adopted from the work of Antia et al. [2001] yields an unrealistic PIC increase in the deep ocean, too low POC:PIC ratios of remineralization, and also a too low mean POC:PIC export ratio.

\section{Effective Carbon Flux}

[37] The calculation of the effective carbon flux is based on three quantities, the sequestration fluxes of organic and inorganic carbon $\left(\mathrm{JPOC}_{\text {sequ }}, \mathrm{JPIC}_{\text {sequ }}\right)$ and $\bar{\Psi}$, the integral ratio of released $\mathrm{CO}_{2}$ :precipitated carbonate (equation (4)). Two sets of $J_{\text {eff }}$ calculations will be performed in section 4.4. In the first set one mean value for $\bar{\Psi}$ will be used together with estimates of $\mathrm{JPOC}_{\text {sequ }}$ adopted from the study of Koeve (submitted manuscript, 2001) and $\mathrm{JPIC}_{\text {sequ }}$ estimated after equation (2), applying the POC:PIC ratio estimates from the exponential RR-Z fit, i.e., with one, regionally invariable, vertical distribution of $R R$ and a regionally constant value of

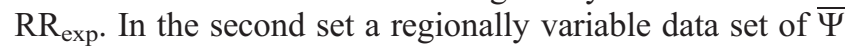

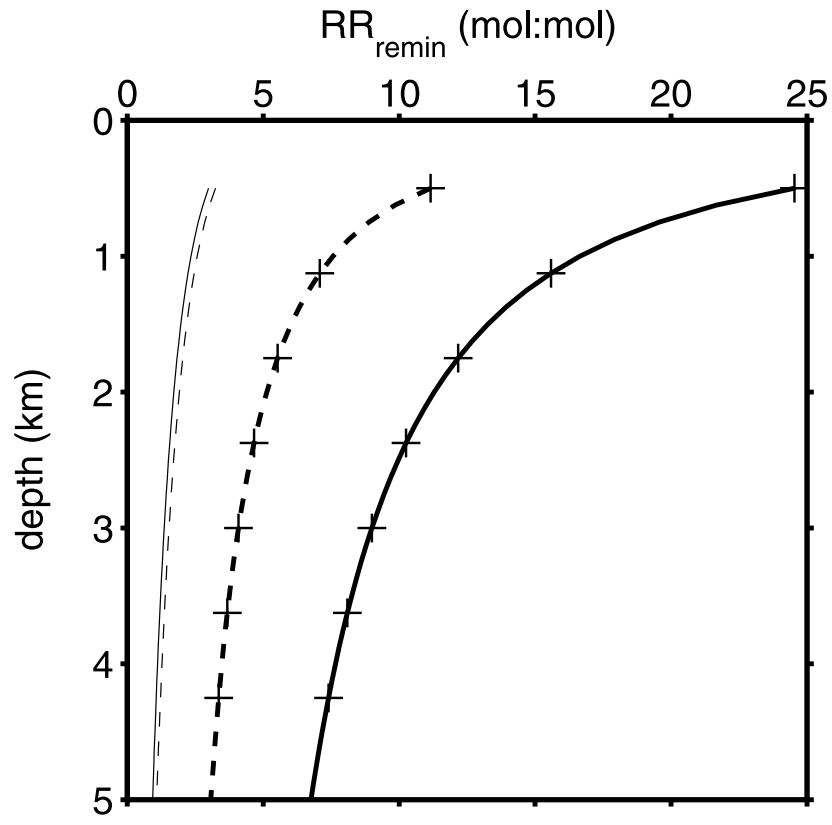

Figure 3. Vertical distribution of the POC:PIC ratio of remineralization. Thick solid line (with plus signs): exponential fit of RR- $Z$ and $b=-0.7$, thick dashed line (with plus signs): exponential fit of RR- $Z$ and $b=-1.0$. Thin solid line: logarithmic fit of the RR- $Z$ function and $b=$ -0.7 , thin dashed line: logarithmic fit of the RR- $Z$ function and $b=-1.0 ; b$ is the $z$-exponent of equation (1).

(section 4.3) will be combined with a data set of $\mathrm{JPIC}_{\text {sequ }}$ which is adjusted to the regional distribution of $R R_{\exp }$ discussed in section 3.2.3 and shown in Figure 2 and with the estimates of $\mathrm{JPOC}_{\text {sequ }}$ from the work of Koeve (submitted manuscript, 2001). In the following three sections, I give a brief description of the distribution of $\mathrm{JPOC}_{\text {sequ }}$ (section 4.1), $\mathrm{JPIC}_{\text {sequ }}$ (section 4.2), and $\bar{\Psi}$ (section 4.3). In section 4.4 the resulting data fields of $J_{\text {eff }}$ are discussed.

\subsection{Distribution of $\mathrm{JPOC}_{\text {sequ }}$}

[38] The distribution of organic carbon fluxes in the Atlantic is discussed in detail in the study of Koeve (submitted manuscript, 2001) and is described here only in brief. Basin scale $\left(65^{\circ} \mathrm{N}-65^{\circ} \mathrm{S}\right)$ integrals of export production computed from eight independent parameter fits (Table 1) of equation (1) varied between 0.9 and $2.9 \mathrm{GT} \mathrm{C} \mathrm{yr}^{-1}$ (Table 5); the respective $\mathrm{ER}_{125}\left(\mathrm{JPOC}_{125} / \mathrm{PP}\right)$, which is an estimate of the $f$-ratio, ranged from 0.07 to 0.31 . Not only overall fluxes and ratios differ, but also their N-S distribution patterns and the relative importance of tropical versus "spring-bloom" biogeographical provinces (Figure 4a). The regional distribution of export production and $\mathrm{ER}_{125}$ was in particular sensitive to the choice of the primary production input data set (data presented by Antoine et al. [1996] versus data presented by Behrenfeld and Falkowski [1997]). The percent fraction of carbon remineralized within the winter mixed layer (Figure $4 b)$ could be estimated more robustly. For the Atlantic Ocean as a whole remineralization within the winter mixed layer reduces the carbon export by $11-17 \%$ (Table 5). In the temperate and subpolar provinces of the North Atlantic, this 
Table 5. Basin Wide Integrals for the North Atlantic ${ }^{\mathrm{a}}$

\begin{tabular}{|c|c|c|c|c|}
\hline & $\begin{array}{l}\text { AM96-Based, }{ }^{b} \\
\text { Means } \pm \text { s.d. }\end{array}$ & $\begin{array}{l}\text { BF97-Based, }{ }^{c} \\
\text { Means } \pm \text { s.d. }\end{array}$ & $\begin{array}{l}\text { Minimum } \\
\text { Estimate }\end{array}$ & $\begin{array}{c}\text { Maximum } \\
\text { Estimate }\end{array}$ \\
\hline Primary production ${ }^{\mathrm{d}, \mathrm{e}}$ & 9.64 & 12.88 & & \\
\hline Export production $\mathrm{d}, \mathrm{e}$ & $2.17 \pm 0.722$ & $1.47 \pm 0.416$ & 0.92 & 2.95 \\
\hline Remineralization ${ }^{\mathrm{d}, \mathrm{e}}$ & $0.26 \pm 0.091$ & $0.25 \pm 0.084$ & 0.14 & 0.35 \\
\hline $\mathrm{JPOC}_{\text {sequ }} \mathrm{d}$, e & $1.91 \pm 0.631$ & $1.21 \pm 0.333$ & 0.77 & 2.60 \\
\hline$\psi \mathrm{JPIC}_{\text {sequ }} \mathrm{d}, \mathrm{f}$ & $0.32 \pm 0.102$ & $0.21 \pm 0.056$ & 0.14 & 0.43 \\
\hline$J_{\text {eff }} \mathrm{d}, \mathrm{f}$ & $1.60 \pm 0.529$ & $1.00 \pm 0.277$ & 0.64 & 2.18 \\
\hline Respiration ratio, ${ }^{\mathrm{e}} r_{\mathrm{R}}-\mathrm{POC}_{\text {sequ }}=\left(\mathrm{JPOC}_{125}-\mathrm{JPOC}_{\text {sequ }}\right) / \mathrm{JPOC}_{125}$ & $0.12 \pm 0.006$ & $0.16 \pm 0.012$ & 0.11 & 0.17 \\
\hline $\mathrm{CaCO}_{3}$ compensation ratio, ${ }^{\mathrm{r}} \mathrm{r}_{\mathrm{CaCO}_{3}}=\psi \times \mathrm{JPIC}_{\text {sequ }} / \mathrm{JPOC}_{125}$ & $0.15 \pm 0.002$ & $0.14 \pm 0.003$ & 0.14 & 0.15 \\
\hline$r_{\mathrm{CaCO}_{3}}{ }^{\mathrm{g}}$ & $0.15 \pm 0.002$ & $0.16 \pm 0.003$ & 0.15 & 0.16 \\
\hline$r_{\mathrm{CaCO}_{3}{ }_{3}}$ & $0.15 \pm 0.003$ & $0.15 \pm 0.004$ & 0.15 & 0.16 \\
\hline$r_{\mathrm{CaCO}_{3}{ }^{3}}$ & $0.14 \pm 0.004$ & $0.14 \pm 0.004$ & 0.13 & 0.14 \\
\hline
\end{tabular}

${ }^{a}$ Estimates are presented for the Atlantic Ocean between $65^{\circ} \mathrm{N}$ and $65^{\circ} \mathrm{S}$; marginal seas like the Baltic, the Hudson Bay, and the Mediterranean are excluded. The integration is based on a $1^{\circ} \times 1^{\circ}$ data set, grid points where the seasonal maximum of the mixed layer depth is equal or larger than the mean water depth at the grid point are ignored.

${ }^{\mathrm{b}}$ AM96-based estimates use the primary production data set of Antoine et al. [1996].

${ }^{\mathrm{c}}$ BF97 based estimates use the primary production data set of Behrenfeld and Falkowski [1997].

${ }^{\mathrm{d}}$ All in GT POC-C-equiv. $\mathrm{yr}^{-1}$; ratios $\left(r_{\mathrm{R}}-\right.$ POCsequ; $\left.r_{\mathrm{CaCO}_{3}}\right)$ are all in mol:mol.

${ }^{\mathrm{e}}$ From Koeve (submitted manuscript, 2001).

${ }^{\mathrm{f}}$ For the standard case: $\psi=0.67 ; \mathrm{RR}_{\mathrm{exp}}=4.37$.

${ }^{\mathrm{g}}$ With $\psi$ from Figure 6a, $\mathrm{RR}_{\exp }$ from Figure 2.

${ }^{\mathrm{h}}$ With $\psi$ from Figure $6 \mathrm{~b}, \mathrm{RR}_{\exp }$ from Figure 2.

${ }^{\mathrm{i}}$ With $\psi$ from Figure $6 \mathrm{~b}, \mathrm{RR}_{\exp }$ as in the standard case.

reduction is equivalent to $37-61 \%$ of the export production. The sequestration of organic carbon, $\mathrm{JPOC}_{\text {sequ }}$ was estimated to range between 0.77 and 2.6 GT C yr ${ }^{-1}$ (Table 5), the regional distribution of the province means of $\mathrm{JPOC}_{\text {sequ }}$ is shown in Figure 4c.

\subsection{Distribution of $\mathrm{JPIC}_{\text {sequ }}$}

[39] The distribution of the PIC export (JPIC 125 , Figure 5a) is basically a scaled plot of the export production, if the POC:PIC flux ratio (RR) is estimated as a function of depth only and $R_{\text {exp }}=R_{125}=$ constant $=4.37$. The estimate of the Atlantic wide integral of $\mathrm{JPIC}_{125}$ ranges from 0.21 to $0.68 \mathrm{GT}$ $\mathrm{C} \mathrm{yr}^{-1}$, PIC dissolution within the winter mixed layer, as predicted from the change of RR over depth, accounts for

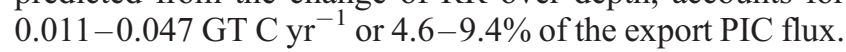
The north-south distribution of the ratio $r_{\mathrm{R}-\mathrm{PICsequ}}$ $\left(=\right.$ Remin $_{\text {PICsequ }} / \mathrm{JPIC}_{125}$ ) (Figure $\left.5 \mathrm{~b}\right)$ is similar to the distribution of the fraction of POC remineralization to POC export production, $r_{\mathrm{R}-\mathrm{PICsequ}}$ (Figure $4 \mathrm{~b}$ ), however, the absolute values of $r_{\mathrm{R} \text {-PICsequ }}$ are always smaller than $r_{\text {R-PICsequ }} \mathrm{JPIC}_{\text {sequ }}$ differs from JPIC 125 mainly in the North Atlantic (Figure 5a, c).

[40] Consequently the POC:PIC flux ratio of carbon sequestration $\left(\mathrm{RR}_{\text {sequ }}=\mathrm{JPOC}_{\text {sequ }} / \mathrm{JPIC}_{\text {sequ }}\right)$ decreases where the difference between POC remineralization and PIC dissolution can take effect, i.e., in the deep mixing regions of the North Atlantic (Figure 5d). North of $42^{\circ} \mathrm{N}$ (NADR, SARC/ ARCT) $R_{\text {sequ }}$ is reduced by about $24-40 \%$ compared to the initial value of $R_{125}$. Since tropical and subtropical regions, which are characterized by low values of $r_{\text {R-PICsequ, }}$ dominate by area, the overall effect of this reduction on the Atlantic wide mean value of $\mathrm{RR}\left(\overline{R R_{\text {sequ }}} \approx 3.9\right)$ is small.

\subsection{Released $\mathrm{CO}_{2}$ : Precipitated Carbonate Ratio, $\psi$ 4.3.1. Mean $\psi$}

[41] The ratio of released $\mathrm{CO}_{2}$ :precipitated carbonate during $\mathrm{CaCO}_{3}$ formation, $\psi$, is controlled by carbonate system chemistry and shows a weak relationship with salinity, a negative correlation with temperature, and a positive correlation with $p \mathrm{CO}_{2}$ [Frankignoulle et al., 1994]. The value of $\psi$ in the surface ocean will mainly vary together with temperature and $p \mathrm{CO}_{2}$. For the early 1990 s, the time period of sediment trap deployments used in this study, an integral value for $\bar{\Psi}=0.67$ can be estimated. This value assumes a mean ocean equilibration temperature of about $15^{\circ} \mathrm{C}$ [Archer et al., 2000b], $S=35$, and a mean surface ocean $p \mathrm{CO}_{2}$ value of $350 \mu \mathrm{atm}$, and is estimated by interpolation of data presented in the study by Frankignoulle et al. [1994] (their Figure 2). This is a more realistic mean value than $\bar{\Psi}=0.6$, which was applied by Antia et al. [2001], since that value requires the mean temperature of the ocean to be $25^{\circ} \mathrm{C}$, for $S=35$ and $p \mathrm{CO}_{2}=350 \mu \mathrm{atm}$ [Ware et al., 1992].

\subsubsection{Regional Distribution of $\psi$ in the Atlantic Ocean}

[42] In the following an estimate of the regional distribution of $\psi$ in the Atlantic is provided. Since these estimates of $\psi$ will be used to compute annual fluxes of $J_{\text {eff }}$, they need to integrate in a suitable way over the depth range between the surface and $Z_{\text {sequ }}$ and over the annual mixing cycle. Accordingly, I have chosen to estimate $\psi$ based on the local mean temperature of the mixed layer at the time of deepest mixing (i.e., during winter). $\mathrm{CaCO}_{3}$ production might take place under conditions of significantly warmer temperatures during summer (i.e., with a smaller $\psi$ ). However, the net effect on the steady state surface ocean $p \mathrm{CO}_{2}$ is fixed at the end of winter time mixing when surface waters, which were "impoverished" in $\mathrm{CO}_{2}$ due to $\mathrm{CO}_{2}$-uptake during new production, have mixed with subsurface waters, which were enriched in $\mathrm{CO}_{2}$ due to remineralization of organic carbon, and high wind speeds have brought the surface ocean, which during this season is characterized by low biological activity and low biogenic $\mathrm{CO}_{2}$ fluxes, as close as possible to equilibrium with the atmosphere. A first estimate $\left(\psi_{350}\right.$, Figure 6a) is based on the assumption that the surface $p \mathrm{CO}_{2}$ 
Latitude

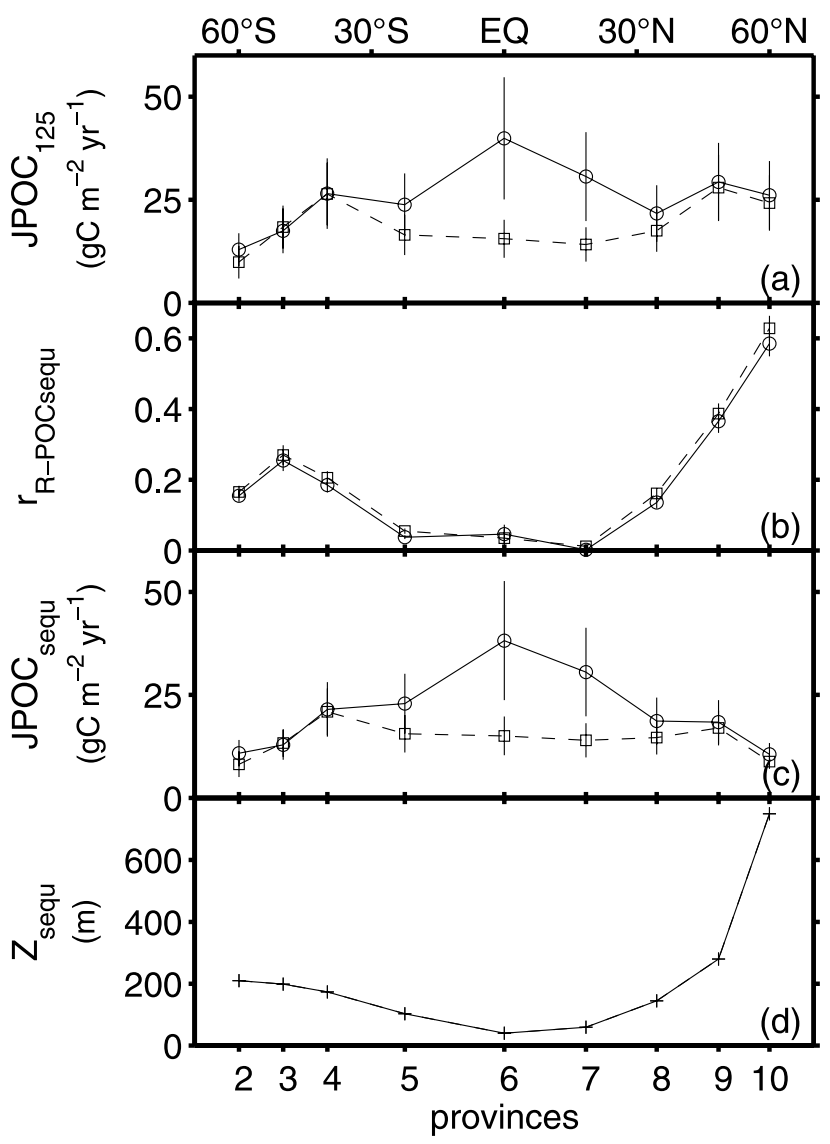

Figure 4. North-South distribution of organic carbon export. Meridional integrals of characteristic open ocean biogeographical provinces, basically following the schema suggested by Longhurst [1998], are presented. Province definitions used in this study are as follows (numbers are as indicated on the lower $x$-axes): (2) Atlantic sectors of the Antarctic Province (ANTA; $65^{\circ} \mathrm{S}-55^{\circ} \mathrm{S}, 70^{\circ} \mathrm{W}-20^{\circ} \mathrm{E}$ ), (3) Subantarctic Water Ring Province (SANT; $55^{\circ} \mathrm{S}-45^{\circ} \mathrm{S}$, $\left.70^{\circ} \mathrm{W}-20^{\circ} \mathrm{E}\right)$, (4) South Subtropical Convergence Province (SSTC; $45^{\circ} \mathrm{S}-35^{\circ} \mathrm{S}, 70^{\circ} \mathrm{W}-20^{\circ} \mathrm{E}$ ), (5) South Atlantic Gyral Province (SATL; $35^{\circ} \mathrm{S}-10^{\circ} \mathrm{S}$ ), (6) Western and Eastern Tropical Atlantic Province (WETRA; $10^{\circ} \mathrm{S}-10^{\circ} \mathrm{N}$ ), (7) North Atlantic Tropical Gyral Province (NATR, $10^{\circ} \mathrm{N}-$ $27^{\circ} \mathrm{N}$, including the Caribbean Province), (8) North Atlantic Subtropical Gyral Province (NAST, $27^{\circ} \mathrm{N}-42^{\circ} \mathrm{N}$, including the Gulf Stream Province), (9) North Atlantic Drift Region (NADR; $42^{\circ} \mathrm{N}-55^{\circ} \mathrm{N}$ ), and (10) the combined Atlantic Subarctic and Arctic Provinces (SARC and ARCT; $55^{\circ} \mathrm{N}-$ $65^{\circ} \mathrm{N}$ ). The following properties are shown: (a) province means of the export production $\mathrm{JPOC}_{125}\left(\mathrm{~g} \mathrm{C} \mathrm{m}^{-2} \mathrm{yr}^{-1}\right)$; (b) $r_{\mathrm{R}-\mathrm{POCsequ}}$, the fraction of POC-remineralization above the winter mixed layer $\left(\mathrm{RPOC}_{\mathrm{sequ}}\right)$ : export production $\left(\mathrm{JPOC}_{125}\right)$; (c) province means of $\mathrm{JPOC}_{\text {sequ }}$, the sequestration flux of organic carbon, $\left(\mathrm{g} \mathrm{C} \mathrm{m}^{-2} \mathrm{yr}^{-1}\right)$; (d) the province mean of $Z_{\text {sequ }}(\mathrm{m})$. Solid lines/circles: means ( \pm standard deviation) of estimates based on primary production forcing data from the study of Antoine et al. [1996], dashed lines/squares: Behrenfeld and Falkowski [1997] based estimates. Modified after the work by Koeve (submitted manuscript, 2001). is in equilibrium with the atmosphere $\left(p \mathrm{CO}_{2 \mathrm{~atm}}=350\right.$ $\mu \mathrm{atm}) . \psi_{350}$ increases from low values $(0.56-0.6)$ in the tropics to $0.7-0.82$ in high latitudes. A second estimate of the distribution of $\psi$, in this case corrected for the deviation of the winter time surface $p \mathrm{CO}_{2}$ from equilibrium with the atmosphere $\psi_{p \mathrm{CO}_{2}}$ insitu is given in Figure $6 \mathrm{~b}$. Both estimates agree within \pm 0.02 mol:mol north of about $40^{\circ} \mathrm{S}$. It is concluded that the specific effect of $\mathrm{CaCO}_{3}$ sequestration on $J_{\text {eff }}$ is sensitive to whether $\mathrm{CaCO}_{3}$ is formed in cold or in warm (high- or low-latitude) waters. As I shall discuss in the next section in more detail, the polarward increase of $\psi$ tends to counteract the polarward increase of the POC:PIC export ratio discussed in sections 3.2.2 and 3.2.3.

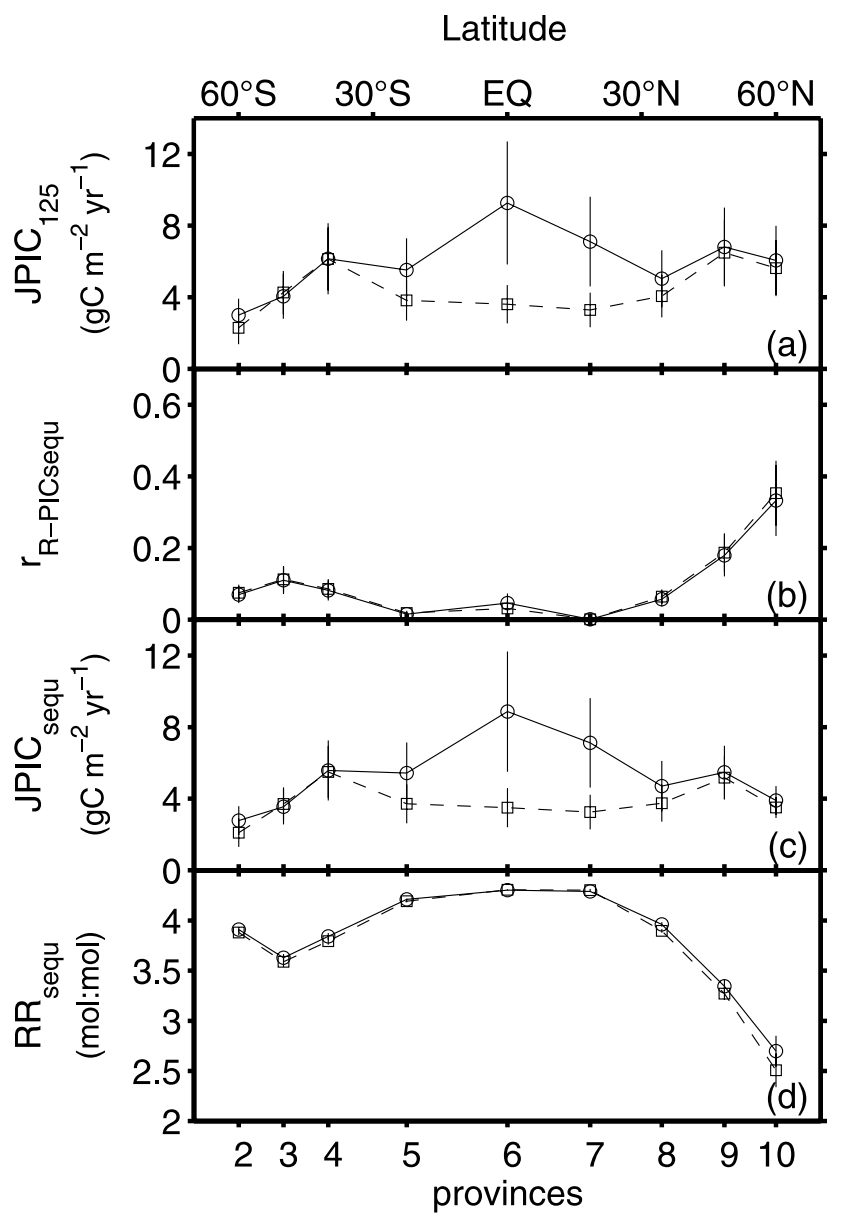

Figure 5. North-south distribution of particulate inorganic carbon fluxes in the Atlantic Ocean. The following properties are shown: (a) province means of the PIC export $\left(\mathrm{JPIC}_{125}, \mathrm{~g} \mathrm{C} \mathrm{m}^{-2} \mathrm{yr}^{-1}\right.$ ), (b) the fraction of PIC dissolution above the winter mixed layer depth, (c) province means of the PIC-sequestration flux ( $\mathrm{JPIC}_{\text {sequ }}, \mathrm{g} \mathrm{C} \mathrm{m}^{-2} \mathrm{yr}^{-1}$ ), and (d) $\mathrm{RR}_{\text {sequ }}$, the POC:PIC flux ratio at $Z_{\text {sequ. }}$ For details see text. Solid lines/circles: estimates based on primary production forcing data from the study of Antoine et al. [1996], dashed lines/squares: estimates based on the work of Behrenfeld and Falkowski [1997]. For province captions see Figure 4. 

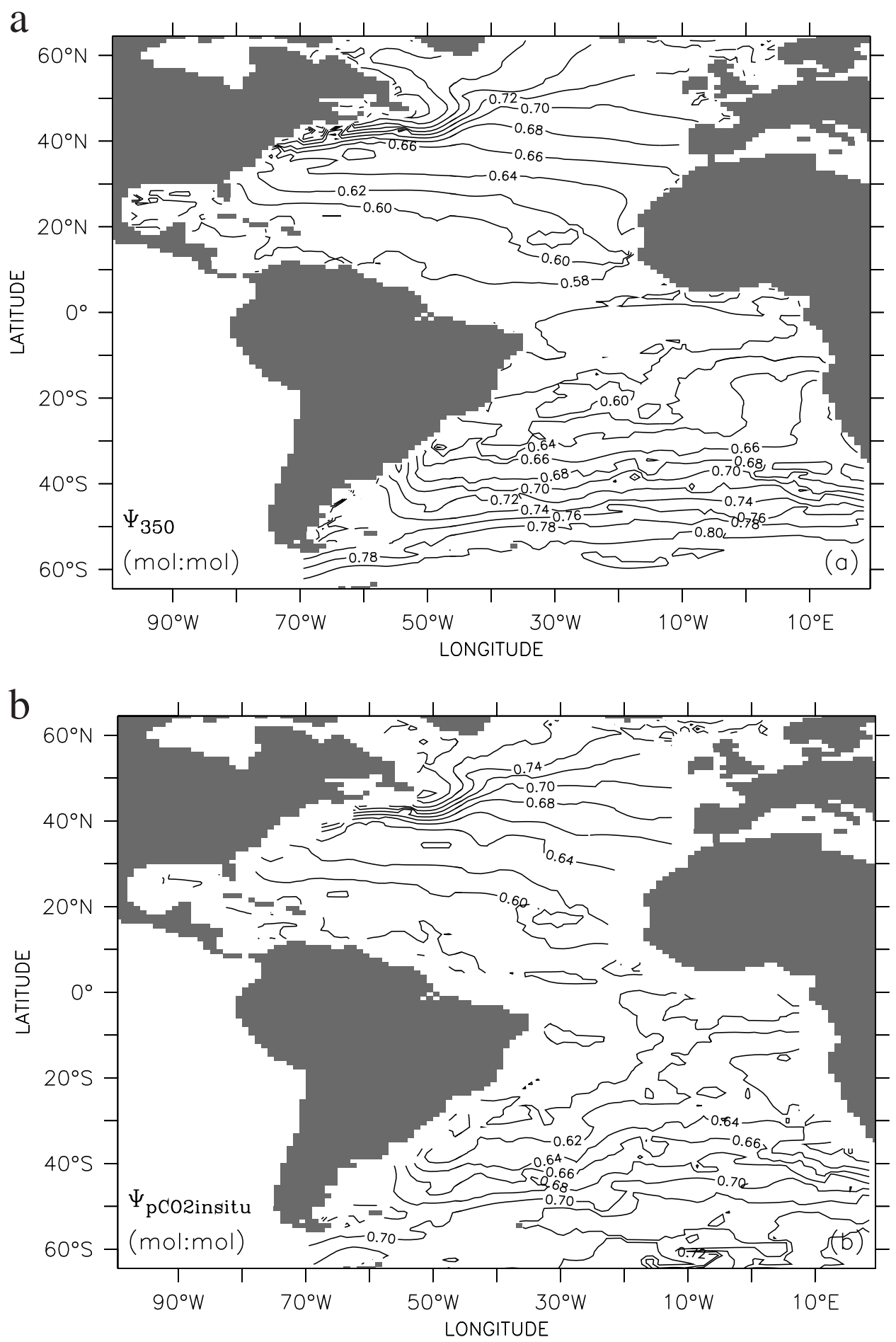

Figure 6. Regional distribution of $\psi$, the integral ratio of released $\mathrm{CO}_{2}$ :precipitated carbonate during

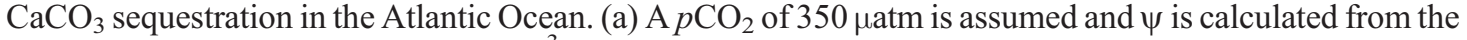
relationship $\psi_{350}=0.8-8.3 \times 10^{-3} \times \mathrm{T}$ [Frankignoulle et al., 1994] where $T$ is the mixed layer temperature during the time of deepest mixing. Temperature data for this computation where taken from the monthly resolving analyzed temperature $\left(1^{\circ} \times 1^{\circ}\right)$ data set of the WOA98 [Antonov et al., 1998]. The time of deepest mixing was estimated from the climatology of mixed layer depths $\left(\Delta \sigma=0.125 \mathrm{~kg} \mathrm{~m}^{-3}\right)$ taken

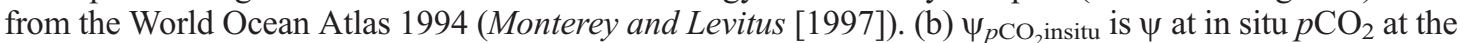
time of deepest mixing, $p \mathrm{CO}_{2(\mathrm{w})} \cdot p \mathrm{CO}_{2(\mathrm{w})}$ is taken from Koeve (unpublished data, 2001), basically it is calculated from a sea-air $\mathrm{CO}_{2}$ difference climatology [Takahashi et al., 1995, 1999] and an estimate of the

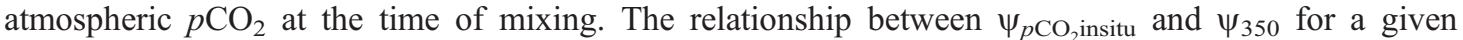
temperature is estimated from a logarithmic fit of data presented in the study by Frankignoulle et al. [1994]. 


\subsection{Distribution of $J_{\text {eff }}$}

[43] The effective carbon flux, $J_{\text {eff }}$, is calculated according to equation (4) from estimates of $\mathrm{JPOC}_{\text {sequ }}$ (Figure $4 \mathrm{c}$ ), $\mathrm{JPIC}_{\text {sequ, }}$ and $\bar{\Psi}$. Several cases are considered. For the standard case (Figure 7a, b) a constant value for $\bar{\Psi}$ of 0.67 is combined with a $\mathrm{JPIC}_{\text {sequ }}$ data set (Figure 5c) which is computed by applying the POC:PIC ratio estimates from the exponential RR-Z fit, i.e., with one, regionally invariable, vertical distribution of RR. Sensitivity computations are carried out by applying estimates of $\psi$ shown in Figures $6 a$ and $b$ and a depth and regionally variable set of $R R$, which is computed from $\mathrm{RR}_{125}$ shown in Figure 2 and the $z$ exponent $(e=-0.56)$ of the exponential RR- $Z$ function. Throughout this section I will distinguish between estimates for which the calculation of the organic fraction $\left(\mathrm{JPOC}_{\text {sequ }}\right)$ is driven by primary production estimates derived by Antoine et al. [1996] (AM96 based estimates) and those by Behrenfeld and Falkowski [1997] (BF97 based estimates).

[44] Estimates of the basin scale integral of $J_{\text {eff }}$ (Table 5) vary between 0.64 and $2.2 \mathrm{GT} \mathrm{C} \mathrm{m}^{-2} \mathrm{yr}^{-1}$, where the higher estimates are based on the AM96 primary production data set and the lower are based on BF97 primary production data. Most of this difference is due to high AM96-based fluxes in tropical and subtropical waters (Figure 7a, b). Elevated tropical and subtropical AM96 based fluxes are a consistent feature which $J_{\text {eff }}$ shares with the distribution of primary

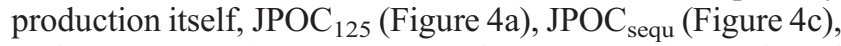
and $\mathrm{JPIC}_{\text {sequ }}$ (Figure $5 \mathrm{c}$ ). On the contrary BF97 based estimates of $J_{\text {eff, in particular the province mean values }}$ (Figure 7b), show little structure along the N-S axes. Maxima in temperate and subpolar waters in both hemispheres, which are evident for the export production $\left(\right.$ JPOC $_{125}$, Figure 4a), have disappeared in the distribution of $J_{\text {eff. }}$ The major process that drives this change in the regional distribution is the shallow remineralization of organic carbon.

[45] The fraction of organic carbon export, which is compensated by the $\mathrm{CaCO}_{3}$ sequestration flux $\left(\mathrm{r}_{\mathrm{CaCO}_{3}}=\right.$ $\left.\psi \times \mathrm{JPIC}_{\text {sequ }} / \mathrm{JPOC}_{125}\right)$ is almost constant everywhere in the Atlantic (Figure 7c). For the standard case a slight reduction can be seen in high latitudes of the North Atlantic due to the effect of shallow PIC dissolution (Figure 5b) in waters with deep winter mixing (Figure 4d). The fraction $r_{\mathrm{CaCO}_{3}}$ is more variable if $\psi$ and $\mathrm{RR}_{\text {exp }}$ are allowed to vary regionally (Figure $7 \mathrm{~d}$ ). The main feature here is a stronger gradient from tropical waters toward mid latitudes and from mid latitudes toward high latitudes in the North Atlantic. $r_{\mathrm{CaCO}_{3}}$ can be up to $50 \%$ larger, like in NAST, compared with the standard case. The basin scale effect of regionally variable values of $\psi$ and $\mathrm{RR}_{\text {exp }}$, however, is small (Table 5). This is mainly due to the fact that the basin scale averages of the data fields of $\mathrm{RR}_{\exp }(4.15)$ and $\psi\left(\psi_{350}=0.66\right.$ and $\psi_{p \mathrm{CO}_{2} \text { insitu }}=0.64$ ) are close to the a priori chosen (or from particle flux data estimated) mean values used in the standard case $\left(\bar{\Psi}=0.67 ; \mathrm{RR}_{\mathrm{exp}}=4.37\right)$. In addition, poleward trends obvious for $\psi_{350}$ or $\psi_{p \mathrm{CO}_{2} \text { insitu }}$ and $\mathrm{RR}_{\exp }$ or $\mathrm{RR}_{\text {sequ }}$ counteract each other and become insignificant on the basin scale. The use of constant values for $\psi$ and $R_{\text {exp }}$ for the basin-scale estimates of $J_{\text {eff }}$ is justified by these findings.

[46] On the basin scale shallow remineralization accounts for $11-17 \%$ and $\mathrm{CaCO}_{3}$ compensation for $14-15 \%$ of

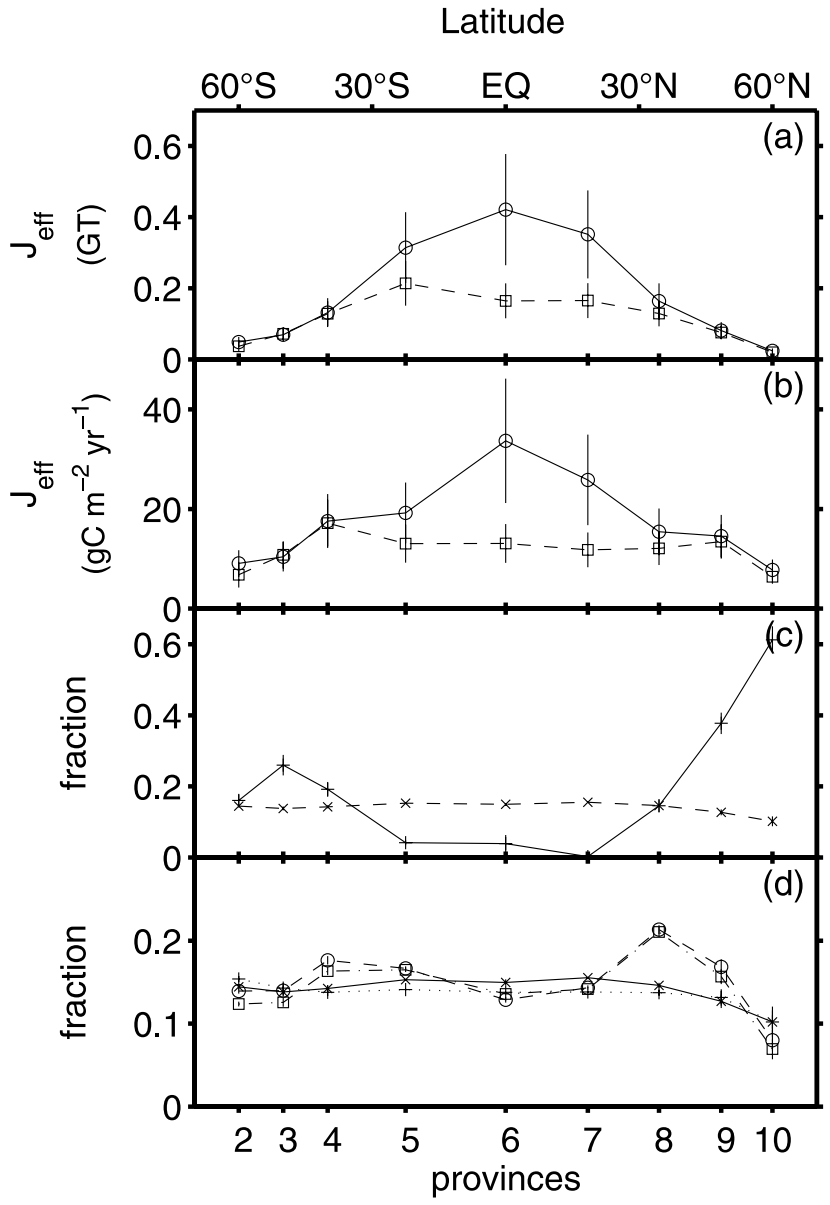

Figure 7. North-south distribution of the effective carbon flux in the Atlantic Ocean. (a-c) Results from the standard case computation (see text). (a) Province integrated $J_{\text {eff }}(\mathrm{GT}$ carbon $\left.\mathrm{yr}^{-1}\right)$. (b) Province means of $J_{\text {eff }}\left(\mathrm{g} \mathrm{C} \mathrm{m}^{-2} \mathrm{yr}^{-1}\right)$. Solid lines/circles: estimates based on primary production forcing data from the work of Antoine et al. [1996], dashed lines/squares: Estimates based on the work of Behrenfeld and Falkowski [1997]. (c) Processes which adjust the difference between $\mathrm{JPOC}_{125}$ and $J_{\text {eff }}$ : solid line (with plus signs) respiration ratio $r_{\mathrm{R}-\mathrm{POC} e q u}=\left(\mathrm{JPOC}_{125}-\mathrm{JPOC}_{\mathrm{sequ}}\right) /$ $\mathrm{JPOC}_{125}$; dashed line (with asterisks) $\mathrm{CaCO}_{3}$ compensation ratio $\psi \times \mathrm{JPIC}_{\text {sequ }} / \mathrm{JPOC}_{125}$. (d) Regional variation of the $\mathrm{CaCO}_{3}$ compensation ratio for different cases: solid line (x) standard case; dashed line (circles) with $\mathrm{RR}_{\text {exp }}$ from Figure 2 and $\psi$ from Figure 6a; dash-dotted line (squares) with $\mathrm{RR}_{\text {exp }}$ from Figure 2 and $\psi$ from Figure $6 \mathrm{~b}$; dotted line (with plus signs) $\mathrm{RR}_{\text {exp }}=4.37$ from the standard run and $\psi$ from Figure 6b. For province captions see Figure 4.

export production. Overall $\mathrm{JPOC}_{\mathrm{exp}}$ overestimates the carbon flux which is effective with respect to surface to deep $\mathrm{CO}_{2}$ gradients by about $30 \%$ for the Atlantic as a whole and for up to $80 \%$ in the subarctic North Atlantic.

\section{Summary and Conclusions}

[47] The POC:PIC ratio of particle flux in the Atlantic Ocean can be described by two empirical relationships with 
almost identical statistics. It is found that a logarithmic fit of the POC:PIC flux ratio and $Z$, which was adopted from the work of Antia et al. [2001], yields an unprecedented increase of PIC flux in the deep ocean and too low POC:PIC ratios of remineralization at intermediate water depths. An exponential fit of the POC:PIC flux ratio over $Z$, on the other hand, yielded remineralization POC:PIC ratios and deep PIC fluxes which are consistent with independent estimates from the literature.

[48] The basin-scale mean POC:PIC ratio of export production $\left(R_{\text {exp }}\right)$ in the Atlantic as estimated from the exponential fit is 4.37. Seasonal changes of nitrate concentrations and alkalinity from temperate and subarctic waters were used in combination with sediment-trap observations from the BATS to construct a map of $R_{\exp }$ which is independent of the deep particle-flux data used elsewhere in this study. Estimates of $R_{\text {exp }}$ ranged between 2 and 9, but the basin-scale integrated value (4.2) agreed with the estimate inferred from deep traps (4.37).

[49] A ratio of organic carbon:inorganic carbon net production, which comprises POC and DOC production, of 6.1-6.9 was recently estimated for the Atlantic by Lee [2001] from an analysis of the seasonal changes of total $\mathrm{CO}_{2}$, alkalinity, and nitrate. The global estimate of the organic carbon:inorganic carbon production ratio of $8.3-$ 9.8 found by Lee [2001], which is close to the range of 10 12.5 suggested from a modeling study by Yamanaka and Tajika [1996] is particularly due to high values in the subtropical Pacific (13.3-17.4) and the southern ocean (7.0-9.9). These ocean to ocean differences of organic: inorganic uptake ratios between the Atlantic and the Pacific resemble the distinction between a "carbonate ocean" (the Atlantic) and a "silicate ocean" (the Pacific) suggested earlier by Honjo [1996].

[50] A map which describes the regional distribution of the vertically and seasonally integrated released $\mathrm{CO}_{2}$ :precipitated carbonate ratio $(\psi)$ during $\mathrm{CaCO}_{3}$ formation is prepared for the early 1990s, the time when most of the particle flux studies used in this study where conducted. $\psi$ varies between values around 0.56 in the tropics to values as high as 0.8 in high latitudes, which indicates that $\mathrm{CaCO}_{3}$ sequestration more effectively compensates POC sequestration in high latitudes than in low latitudes. However, the basin scale integral of $\psi$ has about the same value $(0.64-0.66)$ as the first guess choice for a regionally constant $\psi(0.67)$, which was estimated to be consistent with the mean surface ocean $p \mathrm{CO}_{2}$ equilibration temperature of the contemporary ocean.

[51] Estimates of $J_{\text {eff }}$ ranged from 0.66 to $2.18 \mathrm{GT} \mathrm{C} \mathrm{yr}^{-1}$, this large range is in particular due to the propagation of regional differences of primary production maps [Antoine et al., 1996; Behrenfeld and Falkowski, 1997], which are used as forcing data to estimate the flux of organic carbon in this study. The integrated POC:PIC sequestration flux ratio for the Atlantic ocean is about 3.9, with much lower values in the subarctic North Atlantic. On the basin scale shallow remineralization of $\mathrm{POC}$ and $\mathrm{CaCO}_{3}$ compensation are about equally important in adjusting $J_{\text {eff. }}$ The effect of $\mathrm{CaCO}_{3}$ compensation on POC sequestration shows little regional variations and no correlation with the depth of winter-time mixing. The importance of shallow respiration

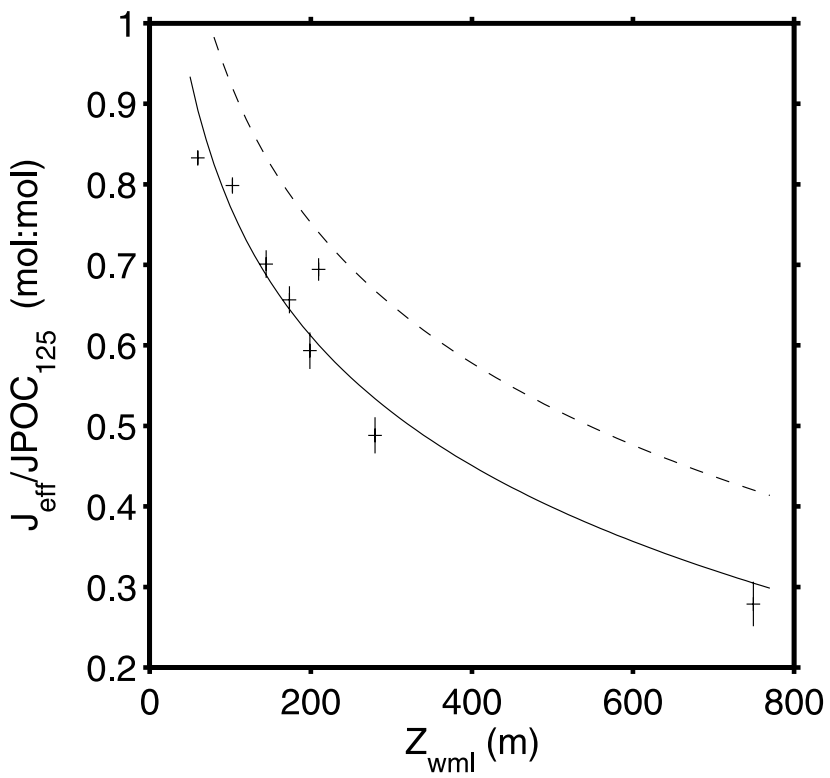

Figure 8. The relation between the province mean of the relative effectivity of the biological pump $\left(\mathrm{eff}=J_{\text {eff }} / \mathrm{JPOC} \mathrm{C}_{125}\right)$ and $Z_{\text {sequ. }}$. Data points are province means ( \pm s.d.); solid line: logarithmic fit to the data $J_{\text {eff }} / \mathrm{JPOC}_{125}=1.84-0.23 \ln (Z)$; $\left.r^{2}=0.925\right)$; dashed line: the respective fit for the ratio $\mathrm{JPOC}_{\text {sequ }} / \mathrm{JPOC}_{125}\left(\mathrm{JPOC}_{\text {sequ }} / \mathrm{JPOC}_{125}=2.08-0.25 \ln (Z)\right.$; $\left.r^{2}=0.926\right)$. The equatorial province WETRA was excluded from this analysis, since the seasonal variability of the mixed layer depth there is meaningless in the context of this study.

for POC sequestration shows more distinct regional patterns. While in tropical and subtropical waters this process is negligible, up to about $61 \%$ of export production is remineralized in high latitude waters in the North Atlantic. The strong link between winter mixed layer depth and the relative effectivity of the biological pump (eff $=J_{\text {eff }} / \mathrm{JPO}$ $\mathrm{C}_{\text {exp }}$ ) is summarized in Figure 8. About $92 \%$ of the variation of $J_{\text {eff }} / \mathrm{JPOC}_{125}$ can be explained by the depth of the winter mixed layer.

[52] With an anticipated change of ocean stratification due to global warming and the intensification of the water cycle [Manabe et al., 1991; Sarmiento et al., 1998], export production likely will change due to reduced nutrient fluxes to the surface ocean and a perhaps prolonged growth season [Bopp et al., 2001]. Much of this change is likely to become compensated by simultaneous changes of $\mathrm{CO}_{2}$ fluxes into the surface ocean [Maier-Reimer et al., 1996].

[53] The increase in the effectivity of the biological pump (rising $J_{\text {eff }} / \mathrm{JPOC}_{\text {exp }}$, Figure 8 ), however, constitutes a negative feedback process which can give rise to an imbalance in ocean carbon fluxes on timescales of the response of ocean circulation and thereby can increase the flux of anthropogenic $\mathrm{CO}_{2}$ flux into the ocean. An example of such a transient imbalance is described in a climate model study by Joos et al. [1999]. There the feedback of the biological pump around year 2100 increases the oceanic $\mathrm{CO}_{2}$-uptake by about $10-15 \%$, and thereby compensates for about $30-40 \%$ 
of the reduction in $\mathrm{CO}_{2}$ uptake from the combined effect of changes in the ocean circulation and the surface ocean temperature (i.e., higher ocean $p \mathrm{CO}_{2}$ due to higher surface ocean temperature and hence a reduced $\mathrm{CO}_{2}$ uptake). Model predictions of the regional distribution of changes in the mixed layer depth [Bopp et al., 2001] would indicate that temperate and subarctic waters, but not the tropics, will be the sites which show the most significant changes in terms of effective carbon fluxes into the deep ocean.

\section{Appendix A: Estimating the Surface Mixed Layer POC:PIC Ratio of Production From Climatological Data}

[54] Operationally it is assumed that the fraction of new carbon production (NP) which is exported via particles can be estimated from the seasonal drawdown of nitrate by multiplying with an appropriate $\mathrm{C}: \mathrm{N}$ ratio of particles (equation (A1)). A C:N ratio of 6.625 [Redfield et al., 1963; Körtzinger et al., 2001a] is used in this study. The seasonal nitrate drawdown $\left(\Delta \mathrm{NO}_{3}\right)$ is estimated as the difference between an estimate of the winter nitrate concentration $\left(\mathrm{NO}_{3(\mathrm{w})}\right)$ and the local minimal nitrate concentration $\left(\min \left(\mathrm{NO}_{3 \text { (seasonal) }}\right)\right.$ observed in the seasonal nitrate climatology [NODC World Ocean Atlas, 1998 (WOA98); Conkright et al., 1998]. The winter nitrate concentration is calculated by applying the integration method of Glover and Brewer [1988] to the annual winter nitrate climatology from WOA98 (equation (A2))

$$
\begin{gathered}
\mathrm{NP}=\mathrm{C} / \mathrm{N} \times \Delta \mathrm{NO}_{3}=\mathrm{C} / \mathrm{N} \times\left[\mathrm{NO}_{3 w}-\min \left(\mathrm{NO}_{3(\text { seasonal })}\right)\right] \\
\mathrm{NO}_{3(\mathrm{~W})}=1 / \mathrm{Z}_{\mathrm{wml}} \times \int_{0}^{\mathrm{Z}_{\mathrm{wml}}} \mathrm{NO}_{3(\text { annual })}
\end{gathered}
$$

[55] The production and export of $\mathrm{CaCO}_{3}$ in the mixed layer, $P_{\mathrm{CaCO}_{3}}$ is estimated analogue to the approach of Robertson et al. [1994] from the seasonal change in potential alkalinity (equation (A3)). Here $\triangle \mathrm{NTA}$ is the seasonal difference of the salinity normalized total alkalinity (NTA). NTA is estimated from regionally variable empirical relationships with temperature [Millero et al., 1998]. Monthly mean temperature values for the calculation of monthly NTA data fields are taken from WOA98 [Antonov et al., 1998]

$$
P_{\mathrm{CaCO}_{3}}=\left[\Delta \mathrm{NTA}+\Delta \mathrm{NO}_{3}\right] / 2
$$

[56] Thereafter the mixed layer POC:PIC ratio of production, $\mathrm{RR}_{\text {mixed-layer, }}$ is estimated as the ratio of $\mathrm{NP} / \mathrm{P}_{\mathrm{CaCO}_{3}}$.

[57] In the subtropics and tropics the seasonal approach cannot be used since seasonal gradients of alkalinity and nitrate vanish. As a substitute for the subtropical bands $\left(10^{\circ}-35^{\circ} \mathrm{N}, 10^{\circ}-35^{\circ} \mathrm{S}\right) \mathrm{I}$ estimate $\mathrm{RR}_{\text {exp }}$ from mass flux and organic carbon flux data from drifting particle interceptor trap measurements $(150 \mathrm{~m}$ depth $)$ at the BATS [Lohrenz et al., 1992]. Since particle flux measurements at BATS do not include measurements of $\mathrm{CaCO}_{3}$ fluxes,
$\mathrm{RR}_{\text {exp }}$ is calculated assuming that the dry weight mass flux consists of organic matter (2.3POC), $\mathrm{CaCO}_{3}$, opal, and a residual terrigenous component [Jickells et al., 1998], and that the opal to $\mathrm{CaCO}_{3}$ ratio and the fraction of terrigenous matter can be extrapolated from deep trap observations from the close-by OFP-site. The long-term mean of the fraction of terrigenous matter in $3200 \mathrm{~m}$ at the OFP-site close to BATS is $18.7 \%$ [Conte et al., 2001] and the opal to $\mathrm{CaCO}_{3}$ weight ratio during the early 1990 s was 0.18 [Deuser et al., 1995]. Using the $z$-exponent of organic carbon flux decreases with depth from Koeve (submitted manuscript, 2001), the $z$-exponent of the $\mathrm{CaCO}_{3}$ exponential flux function (this study) and a temperature dependent decay rate of opal [Gnanadesikan, 1999], a mean terrigenous fraction, and a mean $\left[\mathrm{opal} / \mathrm{CaCO}_{3}\right]_{\text {weight }}$ ratio in $150 \mathrm{~m}$ of $3 \%$ and 0.26 , respectively, are estimated. Mass dry weight and POC data (available from the home page of the BATS Program at http://www.bbsr.edu) from traps deployed at $150 \mathrm{~m}$ between December 1988 and December $1997(n=106)$ are used. The median POC:PIC ratio in 150 $\mathrm{m}$ at BATS calculated from these data is 4.5 , the time integrated annual mean POC:PIC ratio is 4.1. The latter value is used as an estimate of $R_{\text {exp }}$ in the subtropical band $\left(10^{\circ}-35^{\circ}\right)$; in the tropics $\left(10^{\circ} \mathrm{S}-10^{\circ} \mathrm{N}\right)$ an export flux ratio of 4.37 is used (Figure 2).

[58] Acknowledgments. Many people contributed to collecting the original data which form the basis of this study. Special thanks go to Klaus Kremling and Avan N. Antia, both at IfM-Kiel, for their effort in guiding the German JGOFS particle flux synthesis group. The authors wish to acknowledge the use of the Ferret program for data analysis in this paper. Ferret (http://www.ferret.noaa.gov) is a product of NOAA's Pacific Marine Environmental Laboratory. This work was supported by the German JGOFS synthesis program via a grant of the German BMB+F to $G$. Wefer and W. Koeve. Fruitful discussion with A. Oschlies and P. Kähler, both at IfM-Kiel, and helpful comments by two anonymous reviewers helped to clarify the ideas and the presentation.

\section{References}

Antia, A. N., et al., Basin-wide particulate carbon flux in the Atlantic Ocean: Regional export patterns and potential for atmospheric carbon sequestration, Global Biogeochem. Cycles, 15, 845-862, 2001.

Antoine, D., and A. Morel, Oceanic primary production, 1, Adaptation of a spectral light-photosynthesis model in view of application to satellite chlorophyll observations, Global Biogeochem. Cycles, 10, 43-55, 1996.

Antoine, D., J.-M. André, and A. Morel, Oceanic primary production, 2 Estimation at global scale from satellite (coastal zone color scanner) chlorophyll, Global Biogeochem. Cycles, 10, 57-69, 1996.

Antonov, J., S. Levitus, T. P. Boyer, M. Conkright, T. O'Brien, and C .Stephens, World Ocean Atlas 1998, vol. 1, Temperature of the Atlantic Ocean. NOAA Atlas NESDIS 27, p. 166, U.S. Government Printing Office, Washington, D.C., 1998.

Archer, D., Modelling the calcite lysocline, J. Geophys. Res., 96C, 17,037$17,050,1991$.

Archer, D., A data-driven model of the global calcite lysocline, Global Biogeochem. Cycles, 10, 511-526, 1996.

Archer, D., A. Winguth, D. Lea, and N. Mahowald, What caused the glacial/interglacial atmospheric $\mathrm{CO}_{2}$ cycles?, Rev. Geophys., 38, 159189, 2000a.

Archer, D. A., G. Eshel, A. Winguth, W. Broecker, R. Pierrehumbert, and M. Tobis, Atmospheric $p \mathrm{CO}_{2}$ sensitivity to the biological pump in the ocean, Global Biogeochem., 1219-1230, 2000 b.

Asper, V. L., Particle flux in the ocean: Oceanographic tools, in Particle Flux in the Ocean, edited by V. Ittekkot et al., pp. 71-84, John Wiley, New York, 1996.

Bacastow, R., and E. Maier-Reimer, Ocean-circulation model of the carbon cycle, Clim. Dyn., 4, 95-125, 1990.

Balch, W. M., K. A. Kilpatrick, P. Holligan, D. Harbour, and E. Fernandez, The 1991 coccolithophore bloom in the central North Atlantic, 2 Relating 
optics to coccolith concentration, Limnol. Oceanogr., 41, 1684-1696, 1996.

Behrenfeld, M. J., and P. G. Falkowski, Photosynthetic rates derived from satellite-based chlorophyll concentrations, Limnol. Oceanogr., 42, 1-20, 1997.

Berger, W. H., Global maps of ocean productivity, in Productivity of the Ocean: Present and Past, edited by W. H. Berger, V. S. Smetacek, and G. Wefer, pp. 429-455, John Wiley, New York, 1989.

Berger, W. H., K. Fisher, C. Lai, and G. Wu, Oceanic productivity and organic carbon flux, Scr. Inst. Ocean. Ref., 87-30, 1-67, 1987.

Betzer, P. R., W. J. Showers, E. A. Laws, C. D. Winn, G. R. DiTullio, and P. M. Kroopnick, Primary productivity and particle fluxes on a transect of the equator at $153^{\circ} \mathrm{W}$ in the Pacific Ocean, Deep Sea Res., 31, 1-11, 1984.

Bopp, L., P. Monfray, O. Aumont, J.-L. Dufresne, H. Le Treut, G. Madec, L. Terray, and J. C. Orr, Potential impact of climate change on marine export production, Global Biogeochem. Cycles, 15, 81-99, 2001.

Broecker, W. S., and T.-H. Peng, Tracers in the Sea, p. 690, Columbia Univ. Press, New York, 1982.

Brzezinski, M. A., The Si:C:N ratio of marine diatoms: Interspecific variability and the effect of some environmental variables, J. Phycol., 21, 347-357, 1985 .

Brzezinski, M. A., A. L. Alldredge, and L. M. O'Bryan, Silica cycling within marine snow, Limnol. Oceanogr., 42, 1706-1713, 1997.

Buesseler, K. O., Do upper-ocean sediment traps provide an accurate record of particle flux?, Nature, 353, 420-423, 1991.

Buitenhuis, E. T., P. van der Wal, and H. J. W. de Baar, Blooms of Emiliania huxleyi are sinks of atmospheric carbon dioxide: A field and mesocosm study derived simulation, Global Biogeochem. Cycles, 15, 577588, 2001.

Carlson, C. A., H. W. Ducklow, and A. F. Michaels, Annual flux of dissolved organic carbon from the euphotic zone in the northwestern Sargasso Sea, Nature, 371, 405-408, 1994.

Conkright, M., T. O’Brien, S. Levitus, T. P. Boyer, J. Antonov, and C. Stephens, World Ocean Atlas 1998, vol. 10, Nutrients and Chlorophyll of the Atlantic Ocean. NOAA Atlas NESDIS 36, p. 245, U.S. Govt. Print. Off., Washington, D.C., 1998.

Conte, M. H., N. Ralph, and E. H. Ross, Seasonal and interannual variability in deep ocean particle flux at the Oceanic Flux Program (OFP)/ Bermuda Atlantic Time Series (BATS) site in the western Sargasso Sea near Bermuda, Deep Sea Res., Part II, 48, 1471-1505, 2001.

Deuser, W. G., T. D. Jickells, P. King, and J. A. Commeau, Decadal and annual changes in biogenic opal and carbonate fluxes to the deep Sargasso Sea, Deep Sea Res., Part, 42, 1923-1933, 1995.

Doval, M. D., and D. A. Hansell, Organic carbon and apparent oxygen utilization in the western South Pacific and the central Indian Ocean, Mar. Chem., 68, 249-264, 2000.

Eppley, R. W., and B. J. Peterson, Particulate organic matter flux and planktonic new production in the deep ocean, Nature, 282, 677-680, 1979.

Fasham, M. J. R., B. M. Balino, and M. C. Bowles, A new vision of ocean biogeochemistry after a decade of the Joint Global Ocean Flux Study (JGOFS), Ambio Spec. Rep., 10, 4-30, 2001.

Fernandez, E., P. Boyd, P. M. Nolligan, and D. S. Harbour, Production of organic and inorganic carbon within a large-scale coccolithophore bloom in the northeast Atlantic Ocean, Mar. Ecol. Prog. Ser., 97, 271-285, 1993.

Fiadeiro, M., The alkalinity of the deep pacific, Earth Planet Sci. Lett., 49, 499-505, 1980.

Fowler, S. W., and G. A. Knauer, Role of large particles in the transport of elements and organic compounds through the oceanic water column, Prog. Oceanogr., 16, 147-194, 1986.

Frankignoulle, M., C. Canon, and J.-P. Gattuso, Marine calcification as a source of carbon dioxide: Positive feedback of increasing atmospheric $\mathrm{CO}_{2}$, Limnol. Oceanogr., 39, 458-462, 1994.

Glover, D. M., and P. G. Brewer, Estimates of wintertime mixed layer nutrient concentration in the North Atlantic, Deep Sea Res., 35, 1525$1546,1988$.

Gnanadesikan, A., A global model of silicon cycling: Sensitivity to eddy parameterization and dissolution, Global Biogeochem. Cycles, 13, 199220, 1999.

Gust, G., B. R. E. Byrne, P. R. Betzer, and W. Bowles, Particle fluxes and moving fluids: Experience from synchronous trap collections in the Sargasso Sea, Deep Sea Res., 39, 1071-1083, 1992.

Hargrave, B. T., Particle sedimentation in the ocean, Ecol. Modell., 30, 229-246, 1985

Harris, R. P., Zooplankton grazing on the coccolithophore Emiliania huxleyi and its role in inorganic carbon, Mar. Biol., 119, 431-439, 1994.
Holligan, P. M., and W. M. Balch, From the ocean to cells: Coccolithophore optic and biogeochemistry, in Particle Analysis in Oceanography, NATO ASI Ser., vol. G 27, edited by S. Demers, pp. 301-324, Springer-Verlag, New York, 1991.

Holligan, P. M., et al., A biogeochemical study of the coccolithophore, Emiliania huxleyi, in the North Atlantic, Global Biogeochem. Cycles, 7, 879-900, 1993.

Honjo, S., Particle fluxes and modern sedimentation in the Polar Oceans, in Polar Oceanography, Part B, edited by W. O. J. Smith, Academic San Diego, Calif., pp. 687-739, 1990.

Honjo, S., Fluxes of particles to the interior of the open ocean, in Particle Flux in the Ocean, edited by V. Ittekkot et al., pp. 91-154, 1996.

Honjo, S., and S. J. Manganini, Annual biogenic particle fluxes to the interior of the North Atlantic Ocean; studied at $34^{\circ} \mathrm{N} 21^{\circ} \mathrm{W}$ and $48^{\circ} \mathrm{N}$ $21^{\circ} \mathrm{W}$, Deep Sea Res., Part II, 40, 587-608, 1993.

Honjo, S., and M. R. Roman, Marine copepod fecal pellets: Production, transportation and sedimentation, J. Mar. Res., 36, 45-57, 1978.

Jickells, T. D., S. Dorling, W. G. Deuser, T. M. Church, R. Arimoto, and J. M. Prospero, Air-borne dust to a deep water sediment trap in the Sargasso Sea, Global Biogeochem. Cycles, 12, 311-320, 1998.

Joos, F., G.-K. Plattner, T. F. Stocker, O. Marchal, and A. Schmittner, Global warming and marine carbon cycle feedbacks on future atmospheric $\mathrm{CO}_{2}$, Science, 284, 464-467, 1999.

Kähler, P., and E. Bauerfeind, Organic particles in a shallow sediment trap: Substantial loss to the dissolved phase, Limnol. Oceanogr., 46, 719-723, 2001.

Kähler, P., and W. Koeve, Marine dissolved organic matter: Can its C/N ratio explain carbon overconsumption?, Deep Sea Res., Part I, 48, 4962, 2001.

Keir, R. S., The dissolution kinetics of biogenic calcium carbonates in seawater, Geochim. Cosmochim. Acta, 44, 241-252, 1980.

Koeve, W., Wintertime nutrients in the North Atlantic - New approaches and implications for estimates of seasonal new production, Mar. Chem., 74, 245-260, 2001.

Körtzinger, A., W. Koeve, P. Kähler, and L. Mintrop, C:N ratios in the mixed layer during the productive season in the northeast Atlantic ocean, Deep Sea Res., Part I, 48, 661-688, 2001 a.

Körtzinger, A., J. I. Hedges, and P. D. Quay, Redfield ratios revisitedRemoving the biasing effect of anthropogenic CO2, Limnol. Oceanogr., 46, 964-970, $2001 \mathrm{~b}$.

Lee, K., Global net community production estimated from the annual cycle of surface water total dissolved inorganic carbon, Limnol. Oceanogr., 46, 1287-1297, 2001.

Li, Y.-H., T. Takahashi, and W. S. Broecker, Degree of saturation of $\mathrm{CaCO}_{3}$ in the oceans, J. Geophys. Res., 74, 5507-5525, 1969.

Lohrenz, S. E., G. A. Knauer, V. L. Asper, M. Tuel, A. F. Michaels, and A. H. Knap, Seasonal variability in primary production and particle flux in the northwestern Sargasso Sea: U.S. JGOFS Bermuda Atlantic Timeseries Study, Deep Sea Res., 39, 1373-1391, 1992.

Longhurst, A., Ecological geography of the sea, p. 398, Academic, San Diego, Calif., 1998.

Longhurst, A., S. Sathyendranath, T. Platt, and C. Caverhill, An estimate of global primary production in the ocean from satellite radiometer data, $J$. Plankton Res., 17, 1245-1271, 1995.

Louanchi, F., and R. G. Najjar, A global monthly climatology of phosphate, nitrate and silicate in the upper ocean: Spring-summer export production and shallow remineralization, Global Biogeochem. Cycles, 14, 957-977, 2000.

Maier-Reimer, E., U. Mikolajewicz, and A. Winguth, Future ocean uptake of $\mathrm{CO}_{2}$ : Interaction between ocean circulation and biology, Clim. Dyn., 12, 711-721, 1996.

Manabe, S., R. J. Stouffer, M. J. Spelman, and K. Bryan, Transient response of a coupled ocean-atmosphere model to gradual changes of atmospheric $\mathrm{CO}_{2} \mathrm{I}$, annual mean response, J. Clim., 4, 785-818, 1991.

Martin, J. H., G. A. Knauer, D. M. Karl, and W. W. Broenkow, VERTEX: Carbon cycling in the northeast Pacific, Deep Sea Res., 34, 267-285, 1987.

Martin, J. H., S. E. Fitzwater, R. M. Gordon, C. N. Hunter, and S. J. Tanner, Iron, primary production and carbon-nitrogen flux studies during the JGOFS North Atlantic Bloom Experiment, Deep Sea Res., Part II, 40, 115-134, 1993.

Michaels, A. F., M. W. Silver, M. M. Gowing, and G. A. Knauer, Cryptic zooplankton swimmers in upper ocean sediment traps, Deep Sea Res., 37, $1285-1296,1990$.

Millero, F. J., K. Lee, and M. Roche, Distribution of alkalinity in the surface waters of the major oceans, Mar. Chem., 60, 111-130, 1998.

Milliman, J. D., Production and accumulation of calcium carbonate in the ocean: Budget of a non steady state, Global Biogeochem. Cycles, 7, 927957, 1993. 
Milliman, J. D., P. J. Troy, W. M. Balch, A. K. Adams, Y.-H. Li, and F. T. Mackenzie, Biologically mediated dissolution of calcium carbonate above the chemical lysocline?, Deep Sea Res., Part I, 46, 1653-1669, 1999.

Monterey, G., and S. Levitus, Seasonal Variability of Mixed Layer Depth for the World Ocean. NOAA Atlas NESDIS 14, p. 96, U.S. Govt. Print. Off., Washington, D.C., 1997.

Najjar, R. G., J. L. Sarmiento, and J. R. Toggweiler, Downward transport and fate of organic matter in the ocean: Simulations with a general circulation model, Global Biogeochem. Cycles, 6, 45-76, 1992.

Oschlies, A., W. Koeve, and V. Garçon, An eddy-permitting coupled physical-biological model of the North Atlantic, II, Ecosystem dynamics and comparison with satellite and JGOFS local studies data, Global Biogeochem. Cycles, 14, 499-523, 2000.

Pace, M. L., G. A. Knauer, D. M. Karl, and J. H. Martin, Primary production, new production and vertical flux in the eastern Pacific Ocean, Nature, 325, 803-804, 1987.

Peterson, M. N. A., Calcite: Rates of dissolution in a vertical profile in the Central Pacific, Science, 54, 1542-1544, 1966.

Ploug, H., and B. B. Jørgensen, A net-jet flow system for mass transfer and microsensor studies of sinking aggregates, Mar. Ecol. Prog. Ser., 176, 279-290, 1999.

Pomeroy, L. R., and R. E. Johannes, Occurrence and respiration of ultraplankton in the upper $500 \mathrm{~m}$ of the ocean, Deep Sea Res., 15, 381-391, 1968.

Pond, D. W., R. P. Harris, and C. A. Brownlee, Microinjection technique using a $\mathrm{pH}$-sensitive dye to determine the gut $\mathrm{pH}$ of Calanus helgolandicus, Mar. Biol., 123, 75-79, 1995.

Redfield, A. C., B. H. Ketchum, and F. A. Richards, The influence of organisms on the composition of seawater, in The Sea, vol. 2, edited by M. N. Hill, pp. 26-77, John Wiley, New York, 1963.

Richards, F. A., Dissolved silicate and related properties of some western North Atlantic and Caribbean waters, J. Mar. Res., 17, 449-465, 1958.

Riebesell, U. Z. I., B. Rost, P. D. Tortell, R. E. Zeebe, and F. M. M. Morel, Reduced calcification of marine plankton in response to increased atmospheric $\mathrm{CO}_{2}$, Nature, 407, 364-367, 2000.

Riley, G. A., Organic aggregates in seawater and the dynamics of their formation and utilization, Limnol. Oceanogr., 8, 265-279, 1963.

Robertson, J. E., C. Robinson, D. R. Turner, P. Holligan, A. J. Watson, P. Boyd, E. Fernandez, and M. Finch, The impact of a coccolithophore bloom on oceanic carbon uptake in the northeast Atlantic during summer 1991, Deep Sea Res., Part I, 41, 297-314, 1994.

Sambrotto, R. N., J. H. Martin, W. W. Broenkow, C. Carlson, and S. E. Fitzwater, Nitrate utilization in surface waters of the Iceland Basin during spring and summer of 1989, Deep-Sea Res., Part II, 40, 441-458, 1993.

Sarmiento, J. L., R. D. Slater, M. J. R. Fasham, H. W. Ducklow, J. R. Toggweiler, and G. T. Evans, A seasonal three-dimensional ecosystem model of nitrogen cycling in the North Atlantic euphotic zone, Global Biogeochem. Cycles, 7, 417-450, 1993.

Sarmiento, J. L., T. M. C. Hughes, R. J. Stouffer, and S. Manabe, Simulated response of the ocean carbon cycle to anthropogenic climate warming, Nature, 393, 245-249, 1998.

Scholten, J. C., J. Fietzke, S. Vogler, M. Rutgers van der Loeff, A. Mangini, W. Koeve, J. Waniek, P. Stoffers, A. Antia, and J. Kuss, Trapping efficiency of sediment traps from the deep eastern North Atlantic: The ${ }^{230}$ Th calibration, Deep Sea Res., Part II, 48, 2383-2408, 2001.

SCOR, The Joint Global Ocean Flux Study - JGOFS- Science Plan, 61 pp., Scientific Committee on Oceanic Research, International Council of Scientific Unions, Halifax, 1990.

Shaffer, G., Effects of the marine biota on global carbon cycling, in The
Global Carbon Cycle, edited by M. Heimann, pp. 431-455, SpringerVerlag, New York, 1993.

Sigman, D. M., D. C. McCorkle, and W. R. Martin, The calcite lysocline as a constraint on glacial/interglacial low-latitude production changes, Global Biogeochem. Cycles, 12, 409-427, 1998.

Six, K. D., and E. Maier-Reimer, Effects of plankton dynamics on seasonal carbon fluxes in an ocean general circulation model, Global Biogeochem. Cycles, 10, 559-583, 1996.

Sokal, R. R., and F. J. Rohlf, Biometry - The principles and practice of statistics in biological research, 3rd ed., 887 pp., W. H. Freeman, New York, 1995.

Suess, E., Particulate organic carbon flux in the ocean-Surface productivity and oxygen utilization, Nature, 288, 260-263, 1980.

Takahashi, T., Carbonate chemistry of seawater and the calcite compensation depth in the oceans Spec. Publ. Cushman Found, Foramin. Res., 13, $11-126,1975$.

Takahashi, T., W. S. Broecker, and S. Langer, Redfield ratio based on chemical data from isopycnal surfaces, J. Geophys. Res., 90c, 69076924,1985

Takahashi, T., T. T. Takahashi, and S. C. Sutherland, An assessment of the role of the North Atlantic as a $\mathrm{CO}_{2}$ sink, Philos. Trans.R. Soc. London Ser. B, 348, 143-152, 1995.

Takahashi, T., R. H. Wanninkhof, R.A. Feely, R.F. Weiss, D. W. Chipman, N. Bates, J. Olafsson, C. Sabine, and S. C. Sutherland, Net sea-air $\mathrm{CO}_{2}$ flux over the global oceans: An improved estimate based on the sea-air $p \mathrm{CO}_{2}$ difference, Proceedings of the 2nd International Symposium $\mathrm{CO}_{2}$ in the Oceans, Tsukuba, January 1999, CGER-1037-'99, CGER/NIES, pp. 9-15, 1999.

Tsungogai, S., and S. Noriki, Particle fluxes of carbonate and organic carbon in the ocean. Is the marine biological activity working as a sink of the atmospheric carbon?, Tellus, Ser. B, 43, 256-266, 1991.

Turley, C. M., Formation, vertical flux and remineralisation of aggregates in the ocean: A short review, Arch. Hydrobiol. Beih., 37, 155-163, 1992.

Veldhuis, M. J. W., G. W. Kraay, and W. W. C. Gieskes, Growth and fluorescence characteristics of ultraplankton on a north-south transect in the eastern North Atlantic, Deep Sea Res., Part II, 40, 609-626, 1993.

Volk, T., and M. I. Hoffert, Ocean carbon pumps, analysis of relative strengths and efficiencies in ocean-driven atmosphere $\mathrm{CO}_{2}$ changes, in The Carbon Cycle and Atmospheric $\mathrm{CO}_{2}:$ Natural Variations Archean to Present, edited by E. T. Sundquist and W. S. Broecker, pp. 99-110, Geophys. Monogr., AGU, Washington, D.C., 32, 1985.

Ware, J. R., S. V. Smith, and M. L. Reaka-Kudla, Coral reefs: Sources or sinks of atmospheric $\mathrm{CO}_{2}$ ?, Coral Reefs, 11, 127-130, 1992.

Yamanaka, Y., and E. Tajika, The role of the vertical fluxes of particulate organic matter and calcite in the oceanic carbon cycle: Studies using an ocean biogeochemical general circulation model, Global Biogeochem. Cycles, 10, 361-382, 1996.

Zeitzschel, B., P. Diekmann, and L. Uhlmann, A new multisample sediment trap, Mar. Biol., 45, 285-288, 1978.

Zondervan, I., R. E. Zeebe, B. Rost, and U. Riebesell, Decreasing marine biogenic calcification: A negative feedback on rising atmospheric $p \mathrm{CO}_{2}$, Global Biogeochem. Cycles, 15, 507-516, 2001.

W. Koeve, Zentrum für marine Umweltwissenschaften, (Marum), Fachbereich Geowissenschaften (FB5), Universität Bremen, Postfach 330440, D-28334 Bremen, Germany. (w.koeve@web.de; w.koeve@surfeu. de) 